Taxonomy and systematics

\title{
Redescription of Centruroides noxius and description of a closely related new species from western Mexico (Scorpiones: Buthidae)
}

\author{
Redescripción de Centruroides noxius y descripción de una especie nueva estrechamente \\ relacionada de México occidental (Scorpiones: Buthidae) \\ Rolando Teruel $^{\mathrm{a}}$, Javier Ponce-Saavedra ${ }^{\mathrm{b}, *}$, Ana F. Quijano-Ravell ${ }^{\mathrm{c}}$ \\ ${ }^{a}$ Centro Oriental de Ecosistemas y Biodiversidad, Museo de Historia Natural "Tomás Romay”, José A. Saco No. 601, 90100 Santiago de Cuba, Cuba \\ ${ }^{\mathrm{b}}$ Laboratorio de Entomología “Biól. Sócrates Cisneros Paz”, Facultad de Biología, Universidad Michoacana de San Nicolás de Hidalgo, Edificio B-4 2 o piso, \\ Ciudad Universitaria, 58060 Morelia, Michoacán, Mexico \\ ${ }^{\mathrm{c}}$ Programa Institucional de Doctorado en Ciencias Biológicas, Opción en Conservación y Manejo de Recursos Naturales, Universidad Michoacana de San Nicolás \\ de Hidalgo, Edificio R, Ciudad Universitaria, 58060 Morelia, Michoacán, Mexico
}

Received 14 March 2015; accepted 24 July 2015

Available online 5 November 2015

\begin{abstract}
In the present contribution, we redescribe the scorpion species Centruroides noxius Hoffmann, 1932, highly toxic and endemic to western Mexico (state of Nayarit). Its diagnosis is updated according to the modern standards for the genus, and enhanced with a photographic complement that depicts its main diagnostic characters. A new closely related species is also described from the same state, and some comments on the taxonomy and distribution of both taxa are given.

All Rights Reserved (C) 2015 Universidad Nacional Autónoma de México, Instituto de Biología. This is an open access item distributed under the Creative Commons CC License BY-NC-ND 4.0.

Keywords: Taxonomy; New species; Nayarit
\end{abstract}

\section{Resumen}

En la presente contribución, se redescribe Centruroides noxius Hoffmann, 1932, especie de alacrán altamente tóxica y endémica de México occidental (estado de Nayarit). Se actualiza su diagnóstico de acuerdo con los estándares actuales para el género y se mejora con un exhaustivo complemento fotográfico que permite apreciar sus principales caracteres diagnósticos. También se describe una especie nueva estrechamente relacionada que habita en este mismo estado y se hacen algunos comentarios sobre la taxonomía y distribución de ambas especies.

Derechos Reservados (C) 2015 Universidad Nacional Autónoma de México, Instituto de Biología. Este es un artículo de acceso abierto distribuido bajo los términos de la Licencia Creative Commons CC BY-NC-ND 4.0.

Palabras clave: Taxonomía; Nueva especie; Nayarit

\section{Introduction}

In the second part of the classic revision of Mexican scorpions, Hoffmann (1932) described Centruroides noxius, a very singular species that is implicitly associated to Centruroides margaritatus (Gervais, 1841) and its close-relatives, mostly

\footnotetext{
* Corresponding author.

E-mail address: ponce.javier0691@gmail.com (J. Ponce-Saavedra).

Peer Review under the responsibility of Universidad Nacional Autónoma de México.
}

based upon coloration and pedipalp finger dentition. The original description still today gives a good definition of the species: it is thorough and includes 4 good black-and-white photographs.

In the original description, Hoffmann (1932: 283-284) declared $C$. noxius as highly toxic to humans and deemed it to be responsible for repeated deaths of adult people recorded in its area of occurrence. From then on, a plethora of toxicological studies has been continuously published and $C$. noxius has become one of the most widely studied scorpions: the impressive bibliographic catalog of Dupré (2013) listed about 80 papers 
dealing exclusively with this topic. It is obviously inappropriate to expand the present text by quoting all of them, thus we encourage the interested reader to check this thorough compilation and the Internet for those references.

Nevertheless, the taxonomy of $C$. noxius has remained static since its original description, despite such toxicological interest. The most recent papers concerning this species have been focused in toxicological aims (Anguiano, 1999; Bakvy, Zhang, Coffield, Maksymovych, \& Simpson, 1994; Dent, Possani, Ramirez, \& Fletcher, 1980; Frau, Pisciotta, Gurrola, Possani, \& Prestipino, 2001; Hernández, Gazarian, Herion, \& Gazarian, 2002; Jouirou et al., 2004; Rendón-Anaya, Delaye, Possani, \& Herrera-Estrella, 2012; Selisko et al., 2004), and some therapeutic applications (Petricevich, 2006). Thus, as a part of a thorough revision of the Mexican Centruroides currently in progress by our team, we revisit $C$. noxius herein and present the description of a new, closely related species.

\section{Materials and methods}

The specimens were studied, measured and photographed under a Zeiss Stemi 2000C tri-ocular microscope, equipped with line scale and grid ocular micrometers and a Canon PowerShot A620 digital camera. The high-resolution digital photographs were taken using either white or UV light and then slightly processed with Adobe Photoshop CS5, only to remove background and to optimize brightness and contrast parameters for printing. The maps were elaborated with Adobe Photoshop CS5 using maps of the state of Nayarit and Mexican Republic published by Inegi (1997).

Nomenclature and measurements follow Stahnke (1970), except for trichobothriotaxy (Vachon, 1974), metasomal carinae (Francke, 1977), pedipalp chela carinae (Acosta, Candido, Buckup, \& Brescovit, 2008, as interpreted by De Armas, Teruel, \& Kovař́k, 2011), and sternum (Soleglad \& Fet, 2003); unless otherwise noted, all morphologically diagnostic characters mentioned refer to adults of both sexes. As the purpose of the present contribution is taxonomic, the synonymy of every species excludes those references not relevant from that point of view, e.g., mere name citations and toxicological papers whose species identification is unreliable because no voucher specimens or sample origin have been declared. The original description of Hoffmann (1932) is fairly good and detailed, but we opted here to present a complementary description based upon adult topotypes. This serves the double purpose of updating the former according to the modern taxonomic standards for the genus (e.g., De Armas et al., 2011; De Armas \& Martín-Frías, 2003, 2008; Ponce-Saavedra \& Francke, 2004, 2013; Santibáñez-López \& Contreras-Félix, 2013; Teruel, 2000; Teruel, Kovařík, BaldazoMonsivais, \& Hoferek, 2015), and making it entirely comparable to the description of the new species. Measurements are given in millimeters ( $\mathrm{mm})$.

All specimens are preserved in ethanol $80 \%$ and deposited in the following collections: Colección Nacional de Arácnidos, Universidad Nacional Autónoma de México (CNAN), Colección Aracnológica del Laboratorio de Entomología "Biol. Sócrates Cisneros Paz", Universidad Michoacana de
San Nicolás de Hidalgo (CAFBUM) and personal collection Rolando Teruel O. (RTO) in Centro Oriental de Ecosistemas y Biodiversidad (COEyB), Museo de Historia Natural "Tomás Romay", Santiago, Cuba.

\section{Redescription}

Family Buthidae C. L. Koch, 1837

Genus Centruroides Marx, 1890

Centruroides noxius Hoffmann, 1932Figures 1-5, 11. Tables $1-5$

Centruroides noxius Hoffmann, 1932: 246, 279-284; Figs. 62-65. Hoffmann, 1938: 192, 196, 199, 202, 204-205; maps I-II. Díaz-Nájera, 1964: 20, 25. Stahnke and Calos, 1977: 112, 117. Beutelspacher, 2000: 5, 26, 129, 132, 143, 146, 155; maps 1, 112. Fet and Lowe, 2000: 116. Lourenço and Sissom, 2000: 133; app. 5.1. Martín-Frías and De Armas, 2001313, 315; Table 1. De Armas, Martín-Frías, \& Estévez-Ramírez, 2003: 95-96. De Armas, Martín-Frías, \& Paniagua-Solís, 2004: 170; Table I. Ponce-Saavedra and Moreno-Barajas, 2005: 50-51; Tables 1-2. Ponce-Saavedra and Francke, 2013: 77; Table 2.

Centrurus noxius: Díaz-Nájera, 1966: 111-112, 115. DíazNájera, 1975: 3, 27.

Material examined. Mexico: Nayarit: Xalisco Municipality: El Pantanal (type locality); $21^{\circ} 25^{\prime} 38^{\prime \prime} \mathrm{N}, 104^{\circ} 51^{\prime} 35^{\prime \prime} \mathrm{W} ; 926 \mathrm{~m}$.; 2/vi/1978; col. L. Possani; 6 6 $\sigma^{\top}$, 2oq topotypes (RTO: Sco-0250). 16/iv/1991; col. M. Höffner; $3 \sigma^{7} \sigma^{7}$, 2 фq topotypes (RTO: Sco0162).

\section{Diagnosis (emended)}

Adult size moderately small (males $34-48 \mathrm{~mm}$, females $32-47 \mathrm{~mm}$ ) for the genus. Base color brownish, carapace almost entirely covered with dark brown pigmentation, tergites almost entirely covered with dark brown pigmentation, sometimes with a pale median stripe, pedipalps and metasoma with all carinae infuscate, metasomal segments I-IV densely spotted with dark brown between ventral submedian carinae. Pedipalps short and essentially glabrous; manus oval (length/width ratio 1.67-1.72 in males, 1.48-1.51 in females), with carinae strong and coarsely granulose to crenulate; fingers with 8 median rows of granules, basal lobe/notch combination moderately strong. Carapace and tergites with carinae composed of separate, medium-sized, glossy granules; intercarinal surface densely granulose, with scattered medium-sized, glossy granules. Sternite V without smooth patch. Metasoma short, slender, and slightly narrower distally, with 10/8/8/8/0 (male) to 10/8/8/8/5 (female) complete, moderately to strongly developed but fine carinae; ventral submedian carinae serrate on all segments of both sexes, dorsal lateral carinae without conspicuously enlarged terminal denticles; intercarinal spaces matt to rough, in females with many scattered minute granules. Telson incrassate oval, vesicle with small granules scattered and subaculear tubercle spiniform and close to the base of aculeus. Pectines with 17-21 teeth in males and 15-20 in females, basal plate with a moderately sized and deep central pit. 

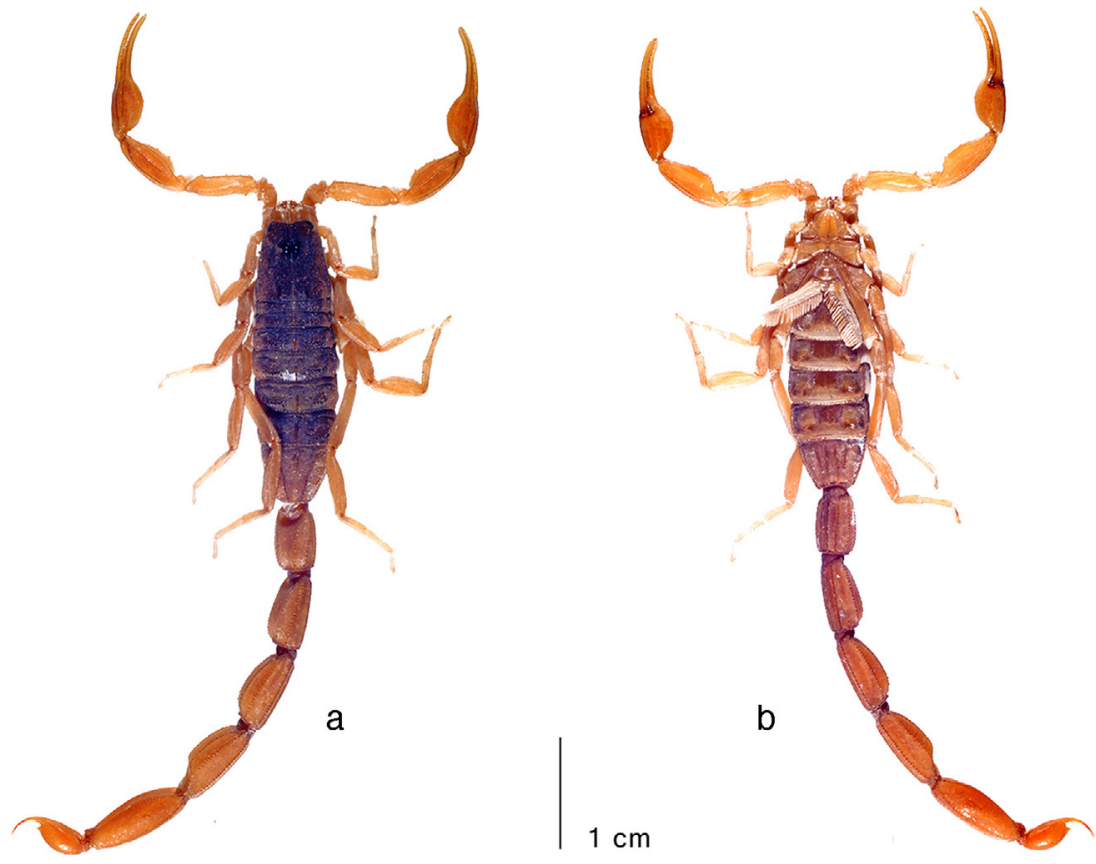

Figure 1. Average-sized adult male (topotype) of Centruroides noxius Hoffmann, 1932, habitus: a, dorsal; b, ventral. Photo courtesy: František Kovařík.

Adult male topotype. Coloration (Fig. 1): base color brownish to ferruginous yellow, slightly lighter on chelicerae, pedipalps, legs, and sternopectinal region, slightly darker on metasomal segment $\mathrm{V}$ and telson. Chelicerae yellowish; manus very densely reticulate with dark brown, with pattern becoming sparser and paler distally; fingers immaculate pale. Pedipalps yellowish; all segments moderately infuscate, denser and darker on carinae; fingers conspicuously paler than manus. Carapace very densely and symmetrically covered with dark brown stains, darker and denser under carinae and coarsely granulose areas; eyes and ocular tubercles black. Tergites I-VI very densely and symmetrically pigmented with dark brown stains but without clearly defined pattern of longitudinal bands (all stains are interconnected by diffuse pigment or reticulations), pretergites and postergites completely pigmented with transversal blackish stripes, lateral margins pale immaculate; VII irregularly densely and symmetrically stained with dark brown, darker and denser under carinae. Coxosternal region and genital operculum yellowish, immaculate. Pectines light reddish-yellow, immaculate. Sternites faint to moderately stained with dark brown, becoming darker and denser both medially and distally toward VII, where spots are arranged into 3 dark stripes (single, wide between median lateral carinae plus paired, thin under lateral carinae), $\mathrm{V}$ with the smooth patch translucent. Legs moderately infuscate, denser and darker along carinae. Metasoma yellowish brown, becoming slightly darker distally; carinae outlined in dark brown, darker on ventral laterals and ventral submedians of segments I-IV; intercarinal spaces immaculate to very faintly infuscate, except for those between ventral submedian carinae of I-IV (very densely stained with dark brown) and dorsally on I. Telson yellowish brown; vesicle faintly infuscate in a stripped pattern formed by 1 narrow ventral submedian and 2 wider lateral, dark stripes (each with a yellowish dot around every setae), separated by thin, pale stripes from each other and also from the faintly infuscate dorsal surface; aculeus faintly infuscate, with distal half blackish.

Chelicerae (Fig. 2c): dentition sharp, surface finely and densely granulose, dorsodistal surface of manus with coarse and glossy granules arranged transversally, defining a flat area. Setation very dense ventrally, but essentially absent dorsally, except for 7 rigid macrosetae around flat area of manus.

Pedipalps (Figs. 1-2a): relatively short and moderately slender, very sparsely setose. Orthobothriotaxic pattern A- $\alpha$. Femur straight, all carinae strongly granulose to serrate, intercarinal surface finely and densely granulose, with many scattered medium-sized granules. Patella straight, all carinae moderately granulose to subcrenulate, intercarinal surface finely and densely granulose. Chela manus short and somewhat slender, slightly wider than patella (ratio 1.08), oval (1.72 times longer than wide), with all carinae moderate, subcostate to granulose, intercarinal surface matt, with many scattered small to medium-sized granules on dorsal and internal surfaces, conspicuously larger and sharper internally; fingers moderately long (movable finger 1.44 times longer than underhand), evenly curved and with $8 / 8$ median rows of granules, each row flanked by 1-3 large supernumerary granules on each side (increasing in number basally), movable finger with an apical subrow of 3 granules plus a large internal granule (large terminal denticle not included), basal lobe/notch combination moderate.

Carapace (Fig. 2c): trapezoidal and slightly longer than wide; anterior margin widely V-shaped, with 2-3 pairs of macrosetae and many microsetae. Carination: the only well-defined carinae are the superciliary (strong, formed by isolated, medium-sized glossy granules) and the posterior median (very strong, formed by isolated, medium-sized glossy granules); other carinae may be present, but coarse intercarinal granulation does not allow 

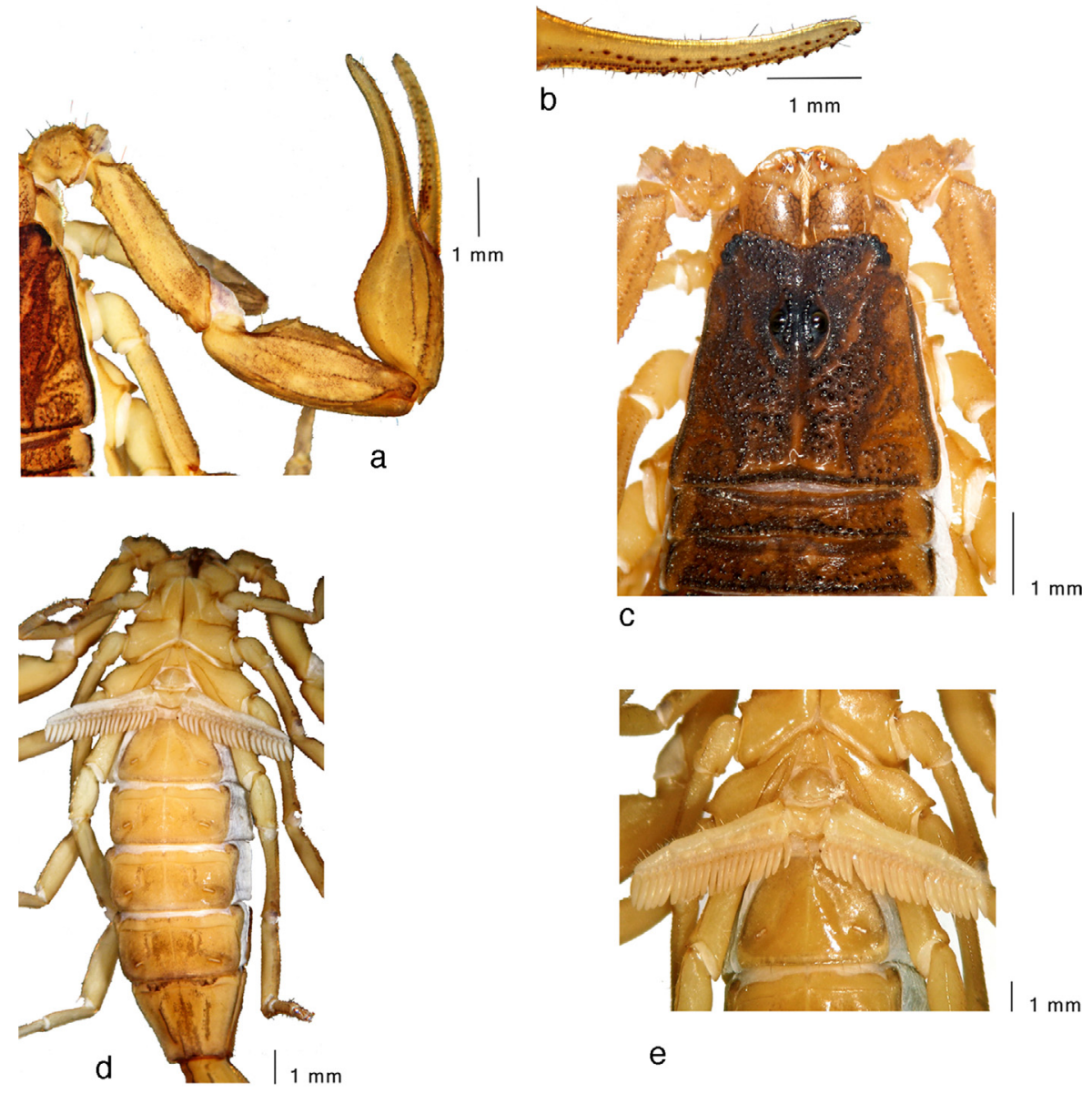

e
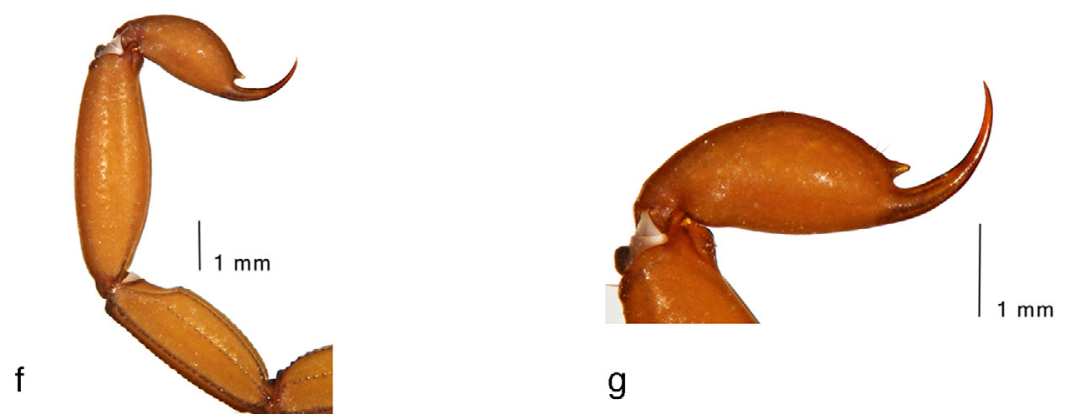

g

Figure 2. Average-sized adult male (topotype) of Centruroides noxius Hoffmann, 1932: a, pedipalp, dorsal view; b, fixed finger, ventral view; c, carapace and tergites I-II; d, trunk, ventral view; e, sternopectinal region; f, metasomal segments IV-V and telson, lateral view; g, telson, lateral view.

an unambiguous distinction. Furrows: anterior median, median ocular, central median, posterior median and posterior marginal fused, wide and moderately deep; posterior laterals long, narrow and shallow; other furrows indistinct. Surface finely and densely granulose with many scattered small and medium-sized granules over all dark patches. Median eyes large, separated by slightly more than one ocular diameter; lateral eyes much smaller, but evenly sized.

Sternum (Fig. 6): type 1, triangular, medium-sized, longer than wide, with 2 pairs of macrosetae.

Genital operculum (Fig. 2e): medium-sized, each half subtriangular in shape, with 2 pairs of macrosetae and a few microsetae. Genital papillae medium-sized, narrowly conical and pointing posteroventrally.
Pectines (Fig. 2e): medium-sized, extending well beyond coxa-trochanter joint of leg IV, sub-rectangular and moderately setose; pectinal tooth count $21 / 21$; basal plate heavily sclerotized, wider than long, anterior margin with a deep, wide anteromedian furrow, posterior margin markedly convex.

Legs (Fig. 1): slender, with all carinae subcrenulate to serrate and intercarinal surface matt to finely granulose. Tibial spurs absent, prolateral and retrolateral pedal spurs well developed in all legs. Ventral surfaces of all telotarsi round and very densely covered with dark macrosetae not arranged into rows, without median row of spinules. Claws long and strongly curved.

Mesosoma (Fig. 2c-e): finely and densely granulose with many scattered small and medium-sized granules over all dark patches; I-VI with only 1 well-defined median longitudinal 

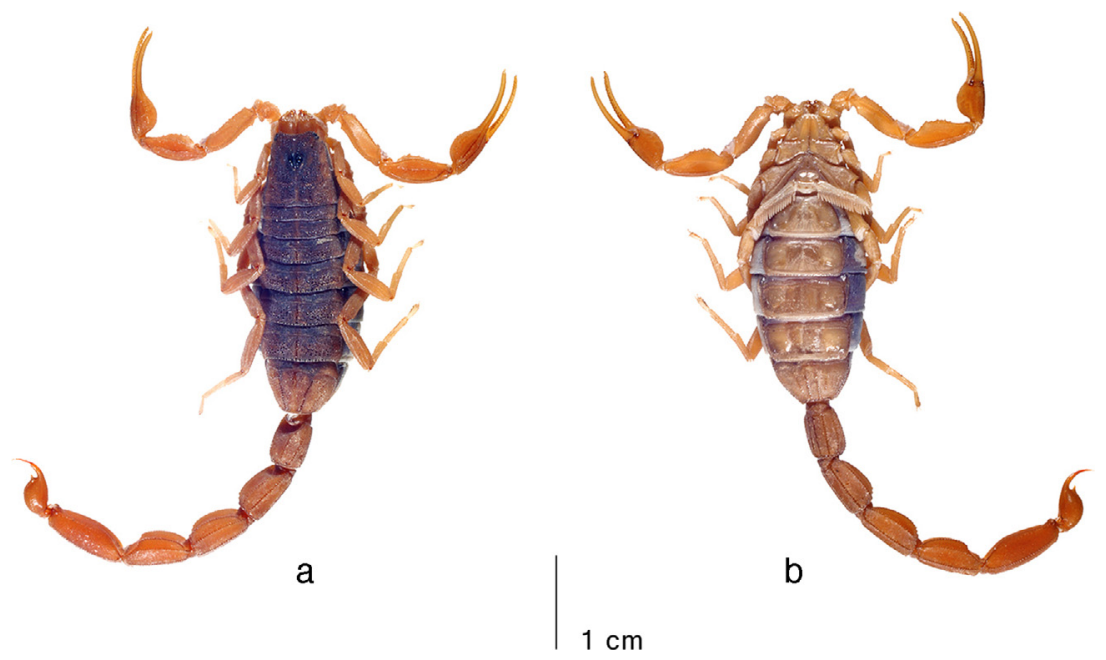

Figure 3. Average-sized adult female (topotype) of Centruroides noxius Hoffmann, 1932, habitus: a, dorsal; b, ventral. Photo courtesy: František Kovařík.

carina (strong, formed by isolated, medium-sized granules that do not project beyond posterior margin), but with irregular traces of an accessory pair of median lateral carinae on IV-VI; VII with five carinae (median, median laterals and laterals) which are long, strong and coarsely serrate. Sternites sparsely setose; III-VI acarinate and glossy but minutely and densely punctate, with minute granules and coarse punctures interspersed; spiracles relatively long and slit-like, $\mathrm{V}$ with smooth patch obsolete and translucent; VII with median lateral and lateral carinae, long and moderately crenulate to serrate, intercarinal surface densely granulose.

Metasoma (Figs. 1 and 2f): somewhat elongated and progressively narrower distally; segment I with 10 complete, fine carinae, II-IV with 8, and V with none (round in cross-section) except for a few vestigial minute granules on ventral median position that suggest a very weak carinae; dorsal lateral carinae strongly serrate on I-II, moderately serrate on III, weakly subserrate on IV; lateral supramedian carinae strongly serrate on I, moderately serrate on II-III, weakly subserrate on IV; lateral inframedian carinae strongly serrate on I and absent on II-IV; ventral lateral carinae strongly serrate on I, moderately serrate on II-III, weakly subserrate on IV; ventral submedian carinae moderately serrate on I-IV; ventral median carinae absent on all segments with the exception indicated in V. Intercarinal surface matt, with abundant scattered minute granules, that become progressively sparser and smaller distally (obsolete on V). Dorsal furrow shallow on all segments. Two pairs of ventrolateral macrosetae, plus some inconspicuous microsetae scattered over all carinae.

Telson (Fig. 2g): sparsely setose, with some inconspicuous, scattered microsetae throughout surface. Vesicle oval (1.92 times longer than wide, 1.06 times wider than deep), surface smooth, matt, ventral median carina obsolete to absent. Subaculear tubercle large and spiniform, close to the base of aculeus, pointing toward its base and smooth. Aculeus conspicuously shorter than vesicle and strongly curved.

Female (topotype: Figs. 3-4; Tables 1, 4-5). Sexual dimorphism reduced, but evident: (1) Pedipalp with manus shorter and narrower; (2) carapace and tergites with glossy granulation coarser; (3) genital papillae absent; (4) pectines slightly narrower and shorter, not reaching the coxa-trochanter joint of leg IV, with slightly lower tooth count; (5) basal pectinal plate larger, with posterior margin more widely convex and with a moderately sized, deep, circular central pit; (6) mesosoma markedly wider, with sides strongly convex; (7) metasomal segments and telson slightly shorter and more robust; (8) metasomal segments with slightly more developed carinae, especially the ventral submedian, ventral laterals, and ventromedian (the last 3 are complete on V).

Variation. Adult size varied in our sample from 34.1 to $40.4 \mathrm{~mm}$ in males $(n=9)$ and 32.1 to $43.2 \mathrm{~mm}$ in females $(n=4)$. Hoffmann (1932) recorded somewhat larger specimens: males 45.3-48.1, females 41.7-46.8. The examined sample contains 2 size-classes among adults of each sex and in each class, males are roughly same-sized as females (Table 1); such correlation deviates from the genus standard, however, already previously described species in which the size of both sexes is statistically similar (e.g., Ponce-Saavedra \& Francke, 2004, 2011). As in other scorpions (e.g., De Armas et al., 2011; Martín-Frías, De Armas, \& Paniagua-Solís, 2005;Teruel, 2000, 2011), smaller adults invariably exhibit the weaker expression of secondary sexual dimorphic characters such as morphometric ratios of pedipalps and metasoma, e.g., small males are more similar to standard females and small females can be confused with subadults if not examined carefully.

The base color presented only minor variations among different individuals, some being subtly paler and some others somewhat darker; in all cases such variation was clearly agerelated, i.e., darker specimens were always the oldest (e.g., cheliceral dentition, leg claws and body setation markedly worn down) and vice versa. Nevertheless, the dark pattern shows 2 different configurations without any intermediate forms (Fig. 5): (1) the pattern described in the original description (Hoffmann, 1932), with infuscation larger and confluent over carapace and tergites; (2) a stripped pattern, with the tergite infuscations arranged into 2 very wide, dark submedian stripes separated 


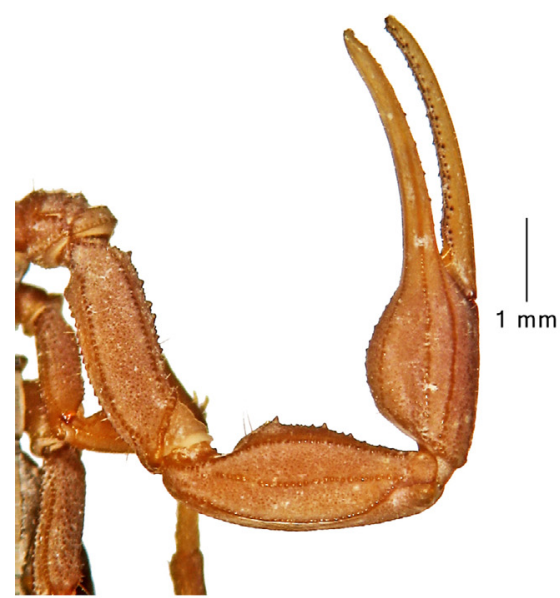

a

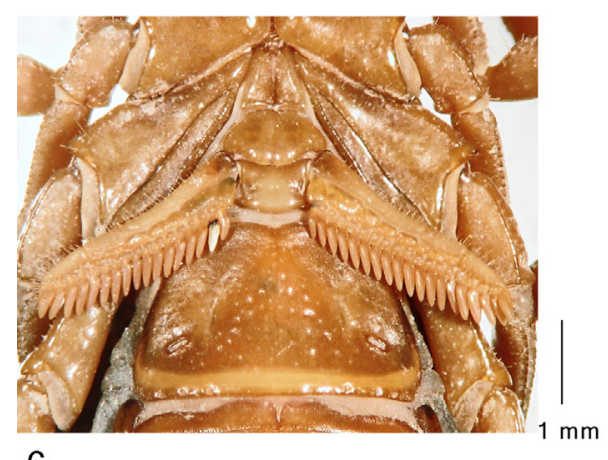

C

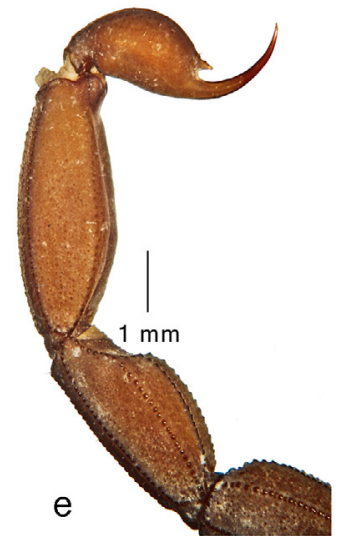

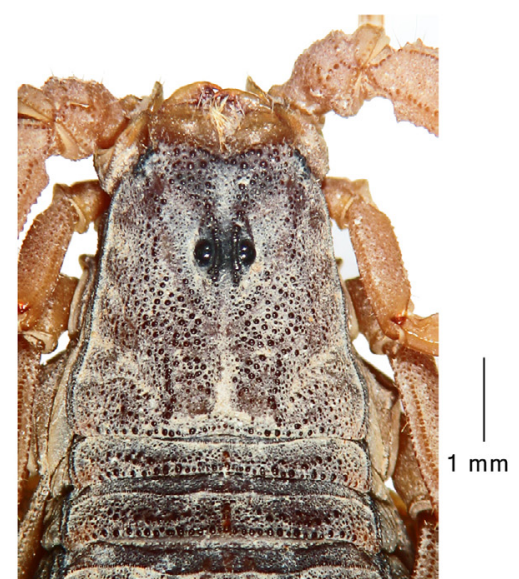

b
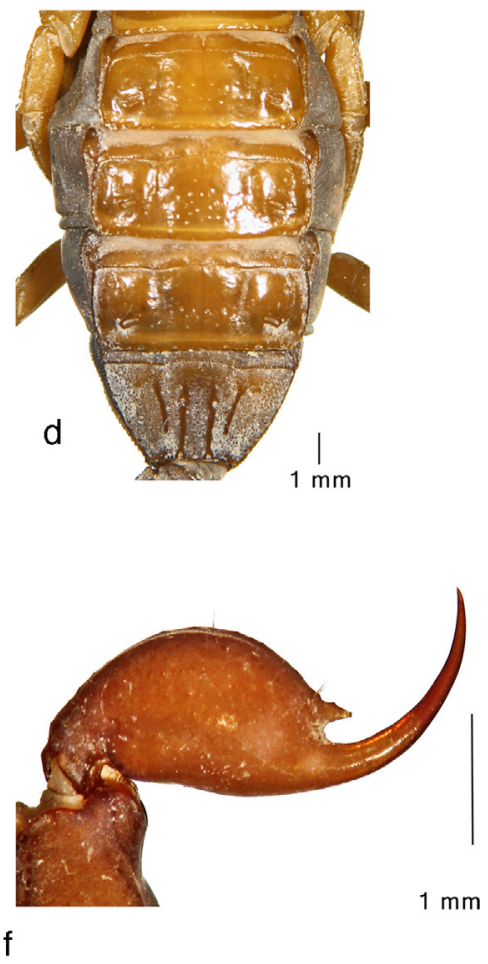

f

Figure 4. Average-sized adult female (topotype) of Centruroides noxius Hoffmann, 1932: a, pedipalp, dorsal view; b, carapace and tergites I-II; c, sternopectinal region; d, sternites IV-VII; e, metasomal segments IV-V and telson, lateral view; f, telson, lateral view.

by a pale median strip, with the pale contour of carapace and mesosoma margins wider.

Pectinal tooth counts variations, presented in Table 5, matches closely the data taken by Hoffmann (1932: 282) from 20 specimens of each sex, all collected at the type locality: 17-21 (mode 19) in males, 15-19 (mode 17) in females.

The number of median rows of granules in pedipalp fingers was 8 in all specimens examined. The apical subrow of movable finger was usually composed of $3 / 3$ granules, but was asymmetrical $(2 / 3)$ between both pedipalps in 2 specimens.

\section{Taxonomic summary}

Distribution (Fig. 11). The precise distribution of C. noxius is not yet satisfactorily clarified. In the original description, Hoffmann (1932) mentioned it from Nayarit and southern Sinaloa, and this has been repeated as such in most posterior references (De Armas et al., 2003, 2004; Beutelspacher, 2000; Díaz-Nájera, 1964, 1966; Fet \& Lowe, 2000; Lourenço \& Sissom, 2000). Nevertheless, Díaz-Nájera (1966) suggested it could occur also in adjacent parts of Jalisco, but Ponce-Saavedra and Francke (2013) listed it only from Nayarit. All specimens that have been studied are from the type locality. 
Table 1

Measurements of 4 topotypes of Centruroides noxius Hoffmann, 1932. Abbreviations: length (L), width (W), posterior width (Wp), depth (D).

\begin{tabular}{|c|c|c|c|c|c|}
\hline \multicolumn{2}{|c|}{ Dimensions (mm) } & \multirow{2}{*}{$\begin{array}{l}\begin{array}{l}\sigma^{7} \\
(\mathrm{Sco}-0250)\end{array} \\
3.05 / 3.30\end{array}$} & \multirow{2}{*}{$\begin{array}{l}\begin{array}{l}\text { の } \\
(\mathrm{Sco}-0250)\end{array} \\
4.10 / 3.95\end{array}$} & \multirow{2}{*}{$\begin{array}{l}\begin{array}{l}q \\
(\mathrm{Sco}-0250)\end{array} \\
3.70 / 3.70\end{array}$} & \multirow{2}{*}{$\begin{array}{l}\stackrel{+}{+} \\
(\text { Sco-0162) }\end{array}$} \\
\hline Carapace & $\mathrm{L} / \mathrm{Wp}$ & & & & \\
\hline Mesosoma & $\mathrm{L}$ & 7.60 & 9.00 & 8.40 & 12.60 \\
\hline Tergite VII & $\mathrm{L} / \mathrm{W}$ & $2.20 / 3.20$ & $2.65 / 3.60$ & $2.40 / 3.85$ & $3.30 / 5.22$ \\
\hline Metasoma & $\mathrm{L}$ & 23.40 & 27.25 & 20.00 & 25.93 \\
\hline Segment I & $\mathrm{L} / \mathrm{W} / \mathrm{D}$ & $2.90 / 1.85 / 1.60$ & $3.30 / 2.15 / 1.70$ & $2.40 / 2.15 / 1.68$ & $3.10 / 2.67 / 2.22$ \\
\hline Segment II & $\mathrm{L} / \mathrm{W} / \mathrm{D}$ & $3.45 / 1.70 / 1.49$ & $4.07 / 2.01 / 1.70$ & $2.85 / 2.00 / 1.69$ & $3.75 / 2.40 / 2.15$ \\
\hline Segment III & $\mathrm{L} / \mathrm{W} / \mathrm{D}$ & $3.90 / 1.70 / 1.50$ & $4.50 / 2.01 / 1.80$ & $3.20 / 1.98 / 1.70$ & $4.12 / 2.47 / 2.22$ \\
\hline Segment IV & $\mathrm{L} / \mathrm{W} / \mathrm{D}$ & $4.22 / 1.67 / 1.60$ & $4.90 / 2.05 / 1.80$ & $3.50 / 1.91 / 1.70$ & $4.50 / 2.40 / 2.22$ \\
\hline Segment V & $\mathrm{L} / \mathrm{W} / \mathrm{D}$ & $4.88 / 1.68 / 1.60$ & $5.80 / 2.03 / 1.79$ & $4.25 / 1.82 / 1.68$ & $5.50 / 2.30 / 2.20$ \\
\hline Telson & $\mathrm{L}$ & 4.05 & 4.68 & 3.80 & 4.96 \\
\hline Vesicle & $\mathrm{L} / \mathrm{W} / \mathrm{D}$ & $2.35 / 1.30 / 1.20$ & $2.88 / 1.50 / 1.42$ & $2.10 / 1.32 / 1.25$ & $2.76 / 1.80 / 1.65$ \\
\hline Aculeus & $\mathrm{L}$ & 1.70 & 1.80 & 1.70 & 2.20 \\
\hline Pedipalp & $\mathrm{L}$ & 12.71 & 15.40 & 12.41 & 16.02 \\
\hline Femur & $\mathrm{L} / \mathrm{W}$ & $3.20 / 0.95$ & $3.88 / 1.12$ & $3.10 / 1.08$ & $4.15 / 1.30$ \\
\hline Patella & $\mathrm{L} / \mathrm{W}$ & $3.71 / 1.29$ & $4.38 / 1.50$ & $3.60 / 1.40$ & $4.40 / 1.70$ \\
\hline Chela & $\mathrm{L}$ & 5.80 & 6.78 & 5.71 & 7.47 \\
\hline Manus & $\mathrm{L} / \mathrm{W} / \mathrm{D}$ & $2.30 / 1.38 / 1.35$ & $2.78 / 1.62 / 1.55$ & $2.10 / 1.42 / 1.32$ & $2.62 / 1.73 / 1.72$ \\
\hline Movable finger & $\mathrm{L}$ & 3.50 & 4.00 & 3.61 & 4.85 \\
\hline Total & $\mathrm{L}$ & 34.05 & 40.35 & 32.10 & 43.18 \\
\hline
\end{tabular}

Table 2

Measurements of 5 types of Centruroides huichol sp. n. Abbreviations: length (L), width (W), posterior width (Wp), depth (D).

\begin{tabular}{|c|c|c|c|c|c|c|}
\hline \multicolumn{2}{|c|}{ Dimensions (mm) } & \multirow{2}{*}{$\begin{array}{l}\begin{array}{l}\sigma^{7} \\
\text { holotype }\end{array} \\
4.00 / 4.00\end{array}$} & \multirow{2}{*}{$\begin{array}{l}\sigma^{7} \\
\text { paratype } \\
3.40 / 3.50\end{array}$} & \multirow{2}{*}{$\begin{array}{l}\begin{array}{l}\sigma^{\pi} \\
\text { paratype }\end{array} \\
3.80 / 3.80\end{array}$} & \multirow{2}{*}{$\begin{array}{l}\text { o } \\
\text { paratype }\end{array}$} & \multirow{2}{*}{$\begin{array}{l}\text { o } \\
\text { paratype } \\
4.78 / 5.00\end{array}$} \\
\hline Carapace & $\mathrm{L} / \mathrm{Wp}$ & & & & & \\
\hline Mesosoma & $\mathrm{L}$ & 9.00 & 9.10 & 12.80 & 8.50 & 13.20 \\
\hline Tergite VII & $\mathrm{L} / \mathrm{W}$ & $2.80 / 3.80$ & $2.60 / 3.22$ & $2.72 / 3.78$ & $2.50 / 4.22$ & $3.40 / 5.40$ \\
\hline Metasoma & $\mathrm{L}$ & 25.70 & 18.44 & 24.05 & 21.06 & 26.64 \\
\hline Segment I & $\mathrm{L} / \mathrm{W} / \mathrm{D}$ & $3.10 / 2.10 / 1.80$ & $2.25 / 2.00 / 1.70$ & $2.85 / 2.12 / 1.81$ & $2.45 / 2.20 / 1.90$ & $3.20 / 2.70 / 2.40$ \\
\hline Segment II & $\mathrm{L} / \mathrm{W} / \mathrm{D}$ & $3.80 / 2.00 / 1.60$ & $2.77 / 1.98 / 1.63$ & $3.50 / 2.10 / 1.80$ & $2.95 / 2.15 / 1.81$ & $3.80 / 2.65 / 2.18$ \\
\hline Segment III & $\mathrm{L} / \mathrm{W} / \mathrm{D}$ & $4.10 / 2.00 / 1.60$ & $3.00 / 1.95 / 1.68$ & $4.00 / 2.10 / 1.80$ & $3.30 / 2.10 / 1.92$ & $4.22 / 2.60 / 2.22$ \\
\hline Segment IV & $\mathrm{L} / \mathrm{W} / \mathrm{D}$ & $4.80 / 2.00 / 1.60$ & $3.30 / 1.88 / 1.68$ & $4.40 / 2.10 / 1.80$ & $3.72 / 2.10 / 2.00$ & $4.70 / 2.63 / 2.30$ \\
\hline Segment V & $\mathrm{L} / \mathrm{W} / \mathrm{D}$ & $5.70 / 2.00 / 1.60$ & $3.85 / 1.80 / 1.63$ & $5.10 / 2.00 / 1.78$ & $4.44 / 2.10 / 1.90$ & $5.50 / 2.61 / 2.30$ \\
\hline Telson & $\mathrm{L}$ & 4.20 & 3.27 & 4.20 & 4.20 & 5.22 \\
\hline Vesicle & $\mathrm{L} / \mathrm{W} / \mathrm{D}$ & $2.80 / 1.70 / 1.50$ & $1.85 / 1.19 / 1.12$ & $2.50 / 1.60 / 1.44$ & $2.20 / 1.55 / 1.40$ & $2.82 / 1.91 / 1.80$ \\
\hline Aculeus & $\mathrm{L}$ & 1.40 & 1.42 & 1.70 & 2.00 & 2.40 \\
\hline Pedipalp & $\mathrm{L}$ & 15.10 & 11.40 & 13.87 & 13.20 & 16.55 \\
\hline Femur & $\mathrm{L} / \mathrm{W}$ & $4.00 / 1.00$ & $2.90 / 0.90$ & $3.60 / 1.00$ & $3.25 / 1.05$ & $4.30 / 1.36$ \\
\hline Patella & $\mathrm{L} / \mathrm{W}$ & $4.20 / 1.40$ & $3.30 / 1.25$ & $4.05 / 1.38$ & $3.70 / 1.40$ & $4.67 / 1.81$ \\
\hline Chela & $\mathrm{L}$ & 6.90 & 5.20 & 6.22 & 6.25 & 7.58 \\
\hline Manus & $\mathrm{L} / \mathrm{W} / \mathrm{D}$ & $2.80 / 1.80 / 1.80$ & $1.90 / 1.40 / 1.32$ & $2.40 / 1.70 / 1.55$ & $2.28 / 1.65 / 1.58$ & $2.98 / 2.08 / 2.05$ \\
\hline Movable finger & $\mathrm{L}$ & 3.80 & 3.30 & 3.82 & 3.97 & 4.60 \\
\hline Total & $\mathrm{L}$ & 38.70 & 30.94 & 40.65 & 33.56 & 44.62 \\
\hline
\end{tabular}

Ecological notes. Almost nothing is known on the ecology of C. noxius, except that Hoffmann (1932) mentioned it occurs in hot lowlands. At least at the type locality it is fairly common: Hoffmann (1932: 279) stated to have studied more than 300 specimens, and during a visit to CNAN collection in July 2014, one of us (RT) examined 2 uncataloged large bottles that contained more than 100 other specimens.

\section{Remarks}

Based upon size, general morphology and coloration, C. noxius is closely related only to a new species which is described in this paper (see below for a detailed comparison).
There is nothing in the original description that indicates Hoffmann (1932) examined other specimens than the actual C. noxius. But our finding of a closely related new species in a site less than $50 \mathrm{~km}$ air-distance from El Pantanal (see below), opens the possibility that part of the records adjudicated to $C$. noxius could in fact represent misidentifications, thus, all records from outside the type locality need to be verified.

This species is remarkable due to the reduction of important sexual secondary characters, which are typically highly dimorphic in most other Centruroides spp., e.g., attenuation of metasoma and pedipalps. Well-fed, small adult males can be mistaken by starving females if not examined carefully enough. 


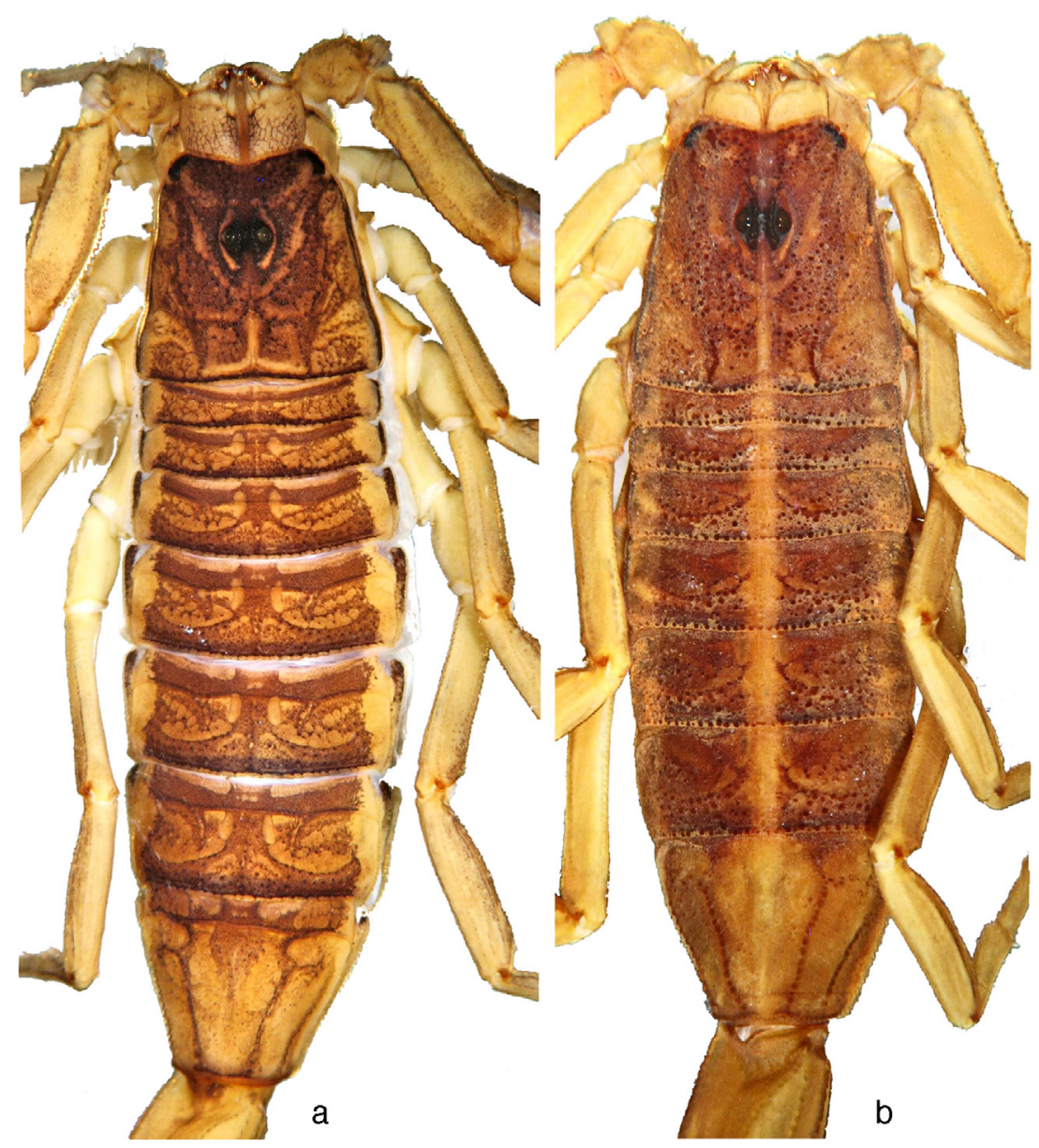

Figure 5. Adult male topotypes of Centruroides noxius Hoffmann, 1932, dimorphic color patterns: a, confluent; b, stripped.

The plethora of toxicological studies conducted on the venom of C. noxius (see a complete list in Dupré, 2013) firmly justifies its inclusion as one of the scorpions most toxic to humans.

\section{Centruroides huichol sp. $n$.}

Figures 6-11. Tables 1-5

Centruroides noxius: Navarro Orozco, 2009: 3, 12, 17, 26, 28-29, 31, 35, 37-41; Fig. 13 (misidentification: specimens and data from Guadalupe Victoria, Nayarit).

\section{Diagnosis}

Adult size moderately small (males $31-41 \mathrm{~mm}$, females $34-45 \mathrm{~mm}$ ) for the genus. Base color reddish yellow to reddish brown, carapace almost entirely covered with dark brown pigmentation, tergites almost entirely covered with dark brown pigmentation, sometimes with a pale median stripe, pedipalps with all carinae infuscate, metasoma with all carinae blackish, metasomal segments I-IV immaculate between ventral submedian carinae. Pedipalps short and essentially glabrous; manus globose (length/width ratio 1.36-1.41 in males, 1.38-1.43 in females), with carinae strong and coarsely costate to subgranulose; fingers with 8 median rows of granules, basal lobe/notch combination moderately strong. Carapace and tergites with carinae composed of partially fused, coarse and glossy granules; intercarinal surface densely granulose, with scattered coarse, glossy granules. Sternite V without smooth patch. Metasoma short, robust, and slightly narrower distally, with $10 / 8 / 8 / 8 / 0$ (male) to $10 / 8 / 8 / 8 / 3$ (female) complete, weakly to moderately developed but coarse carinae; ventral submedian carinae smooth on segment I of both sexes and also on II of male, dorsal lateral carinae without conspicuously enlarged terminal denticles; intercarinal spaces matt to glossy, with a few scattered minute granules. Telson inflate oval, vesicle smooth, with subaculear tubercle spiniform and close to the base of aculeus. Pectines with 18-21 teeth in males and 17-19 in females, basal plate in females with a large and very deep central pit.

Adult male holotype. Coloration (Fig. 6): base color reddish yellow to brownish, lighter on chelicerae, pedipalp femur, patella and fingers, legs, and sternopectinal region, darker on pedipalp chela, metasomal segments IV-V and telson. Chelicerae reddish yellow; manus very densely reticulate with blackish brown, with pattern becoming denser and darker distally, but sparser and fainter basally; fingers deeply infuscate. Pedipalps reddish yellow, becoming gradually darker and redder distally; all segments faintly infuscate, much denser and darker on carinae; fingers reddish yellow, conspicuously paler than manus. Carapace very densely and symmetrically covered with dark brown stains, all stains are interconnected, but separated by a pale longitudinal stripe that extends from behind median ocular tubercle through posterior margin, stains darker and denser under carinae 


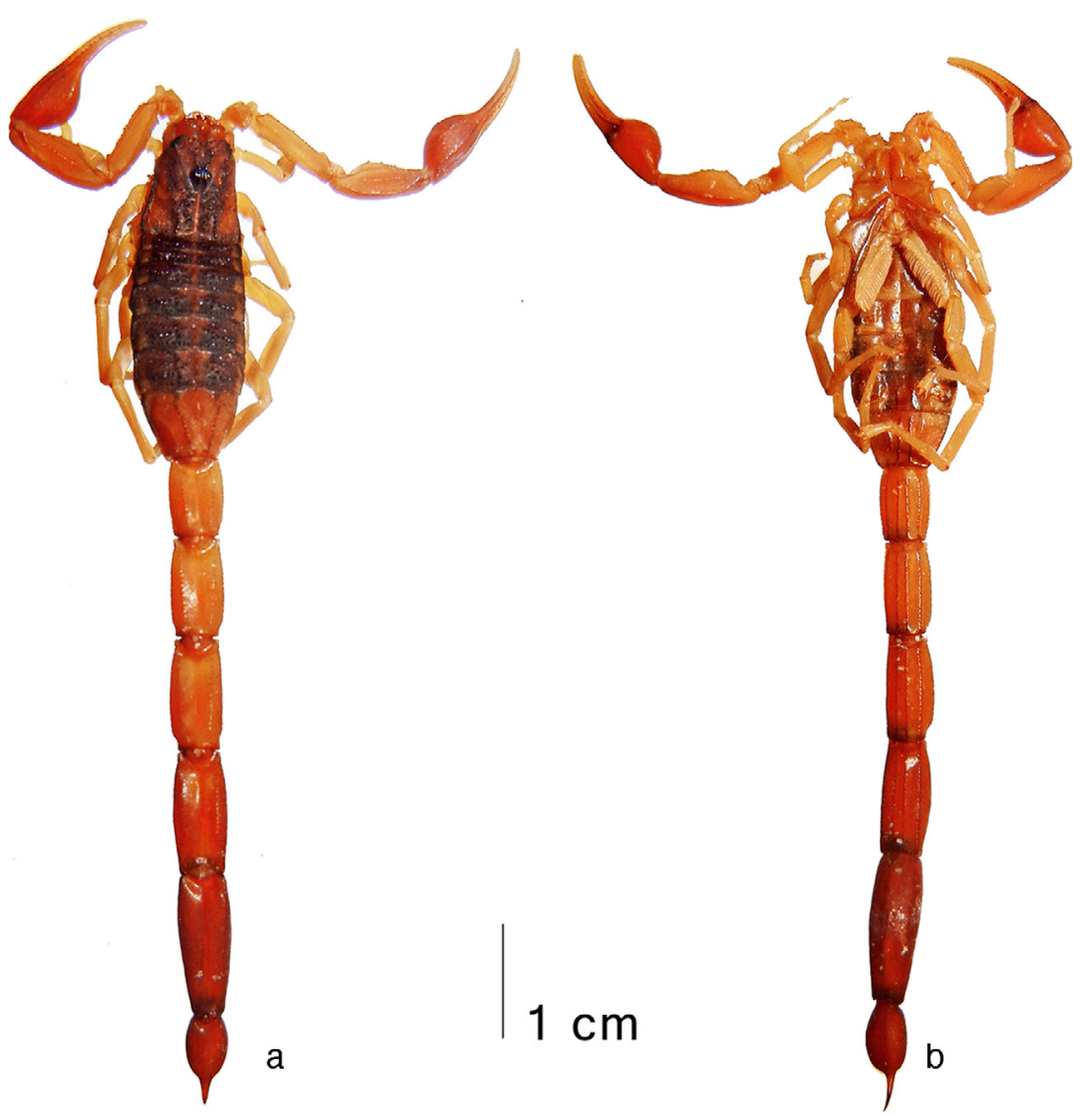

Figure 6. Average-sized adult male (holotype) of Centruroides huichol sp. n., habitus: a, dorsal; b, ventral.

Table 3

Morphometric comparison between adult males of Centruroides noxius Hoffmann, 1932 (topotypes, $n=4$ ) and its closest relative Centruroides huichol sp. n. (types, $n=4$ ), based on a selection of 6 measurements and 7 ratios. Total length has been included as a comparative complement. Abbreviations: length (L), width (W), depth (D), standard deviation (SD).

\begin{tabular}{lcc}
\hline Variable & $\begin{array}{l}\text { C. } \text { noxius } \\
(\text { mean } \pm \text { SD) }\end{array}$ & $\begin{array}{l}\text { C. huichol } \text { sp. } \mathrm{n} . \\
\text { (mean } \pm \text { SD) }\end{array}$ \\
\hline Pedipalp manus (L) & $2.57 \pm 0.22$ & $2.14 \pm 0.22$ \\
Metasoma (L) & $26.14 \pm 2.39$ & $21.21 \pm 2.64$ \\
Metasomal segment I (L) & $3.20 \pm 0.24$ & $2.61 \pm 0.28$ \\
Metasomal segment II (L) & $3.88 \pm 0.38$ & $3.21 \pm 0.31$ \\
Metasomal segment III (L) & $4.28 \pm 0.39$ & $3.50 \pm 0.44$ \\
Telson vesicle (L) & $2.71 \pm 0.29$ & $2.04 \pm 0.32$ \\
Pedipalp manus (L/W) & $1.60 \pm 0.11$ & $1.40 \pm 0.03$ \\
Metasomal segment II (L/W) & $1.99 \pm 0.08$ & $1.63 \pm 0.18$ \\
Metasomal segment IV (L/W) & $2.42 \pm 0.12$ & $2.00 \pm 0.20$ \\
Metasomal segment I (L/D) & $1.82 \pm 0.09$ & $1.50 \pm 0.13$ \\
Metasomal segment IV (L/D) & $2.65 \pm 0.09$ & $2.22 \pm 0.24$ \\
Telson vesicle (L/W) & $1.80 \pm 0.08$ & $1.54 \pm 0.03$ \\
Telson vesicle (L/D) & $1.90 \pm 0.12$ & $1.67 \pm 0.06$ \\
Total (L) & $34.05-42.68$ & $30.94-40.65$ \\
\hline
\end{tabular}

and coarsely granulose areas; eyes and ocular tubercle black. Tergites I-VI with 2 very large, squared blackish stains that compose a wide longitudinal pair of dark submedian stripes separated by a pale median stripe; VII with the same stains smaller, subtriangular and restricted to anterior portion, but extending as thin lines under median lateral carinae. Coxosternal region and genital operculum reddish yellow, faintly infuscate. Pectines reddish, with basalmost portion and basal plate densely infuscate. Sternites very densely infuscate, on III-VI arranged more or less clearly into 4 wide dark stripes (paired submedian and lateral stripes) plus a thin median dark line, $\mathrm{V}$ with the smooth patch translucent whitish. Legs very faintly infuscate. Metasoma reddish yellow, becoming gradually darker and redder distally; carinae outlined in black, much wider and darker on ventral laterals and ventral submedians of segments I-IV; intercarinal spaces immaculate to very faintly infuscate, slightly denser on V. Telson reddish; vesicle moderately infuscate in a stripped pattern formed by 1 ventral submedian and 2 wide lateral dark stripes (each with a yellowish dot around every setae), separated by thin, pale stripes from each other and also from the faintly infuscate dorsal surface; aculeus deeply infuscate, with distal half blackish.

Chelicerae (Fig. 7c): dentition sharp, surface finely and densely granulose, dorsodistal surface of manus with coarse and glossy granules arranged transversally, defining a flat area. Setation very dense ventrally, but essentially absent dorsally, except for 5 rigid macrosetae around depressed area of manus.

Pedipalps (Figs. 6-7a): relatively short and only slightly slender, noticeably sparsely setose. Orthobothriotaxic pattern A- $\alpha$. Femur straight, all carinae moderately granulose to strongly serrate, intercarinal surface finely and densely granulose, with many scattered medium-sized granules. Patella straight, all carinae moderately granulose to strongly costate, intercari- 


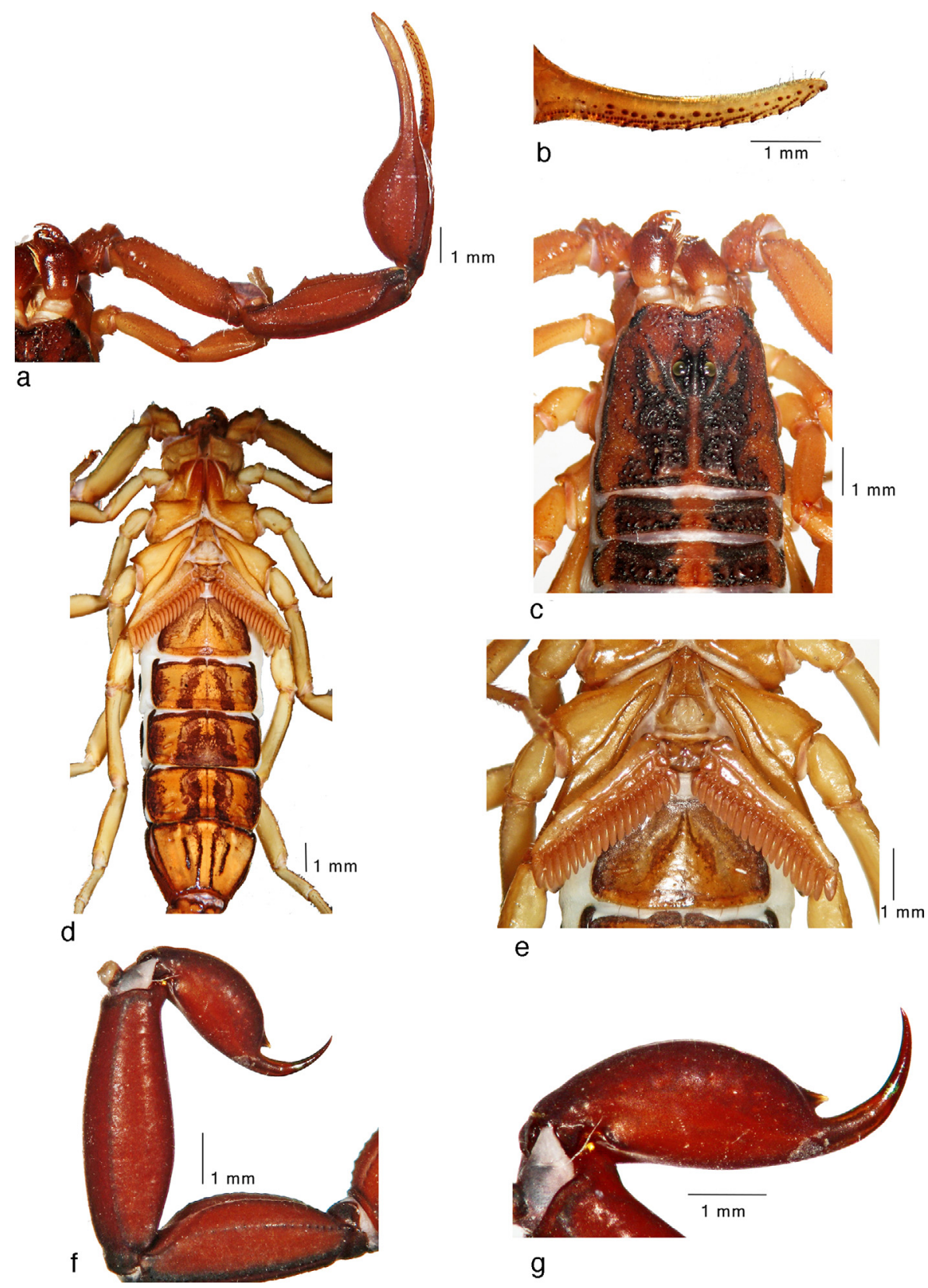

Figure 7. Average-sized adult male (paratype) of Centruroides huichol sp. n.: a, pedipalp, dorsal view; b, fixed finger, ventral view; c, carapace and tergites I-II; $\mathrm{d}$, trunk, ventral view; e, sternopectinal region; f, metasomal segments IV-V and telson, lateral view; g, telson, lateral view.

nal surface finely and densely granulose. Chela manus short and robust, markedly wider than patella (ratio 1.29), globose (almost as wide as deep), with all carinae strong, coarsely costate to subgranulose, intercarinal surface matt, with scattered small to medium-sized granules on dorsal and internal surfaces; fingers thick but moderately long (movable finger 1.36 times longer than underhand), evenly curved and with $8 / 8$ median rows of granules, each row flanked by 1-3 large supernumerary granules on each side (increasing in number basally), movable finger with an apical subrow of 2-3 granules plus a large internal granule (large terminal denticle not included), basal lobe/notch combination moderately strong.
Carapace (Fig. 7c): trapezoidal and as long as wide; anterior margin widely V-shaped, with 2 pairs of macrosetae and many microsetae. Carination: the only well-defined carinae are the superciliary (very strong, formed by partially fused coarse and glossy granules) fused to the anterior medians (very strong, formed by isolated coarse and glossy granules) and the posterior medians (very strong, formed by partially fused coarse and glossy granules); other carinae may be present, but coarse intercarinal granulation does not allow an unambiguous distinction. Furrows: anterior median, median ocular, central median, posterior median and posterior marginal fused, wide and moderately deep, posterior laterals long, narrow and shallow, other furrows indistinct. Surface very finely and densely granulose, 
with many scattered, medium-sized and coarse, glossy granules over all dark patches. Median eyes large, separated by slightly more than one ocular diameter; lateral eyes much smaller, but evenly sized.

Sternum (Fig. 7e): type 1, triangular, medium-sized, longer than wide, with 2 pairs of macrosetae.

Genital operculum (Fig. 7e): medium-sized, each half subtriangular in shape, with 2 pairs of macrosetae and a few microsetae. Genital papillae medium-sized, narrowly conical and pointing posteroventrally.

Pectines (Fig. 7e): medium-sized, extending beyond coxa-trochanter joint of leg IV, sub-rectangular and moderately setose; tooth count 18/20; basal plate heavily sclerotized, much wider than long, anterior margin with a deep, narrow anteromedian furrow, posterior margin essentially straight.

Legs (Fig. 6): slender, with all carinae subcrenulate to serrate and intercarinal surface matt to minutely granulose. Tibial spurs absent, prolateral and retrolateral pedal spurs well developed in all legs. Ventral surface of all telotarsi round and very densely covered with dark macrosetae not arranged into rows, without median row of spinules. Claws long and strongly curved.

Mesosoma (Fig. 7c-e): very finely and densely granulose, with many scattered, medium-sized and coarse, glossy granules over all dark patches; I-VI with only 1 well-defined median longitudinal carina (very strong, formed by partially fused coarse and glossy granules that do not project beyond posterior margin), but with irregular traces of an accessory pair of median lateral carinae on IV-VI; VII with 5 carinae (median, median laterals and laterals) which are long, strong and coarsely crenulate to serrate. Sternites sparsely setose; III-VI acarinate and glossy but minutely and densely punctate, with minute granules and coarse punctures interspersed, spiracles relatively short but slitlike, V with smooth patch indistinct and translucent whitish; VII with median lateral and lateral carinae, long and coarsely subcrenulate to subcostate, intercarinal surface matt to finely and densely granulose.

Metasoma (Fig. 7f): only slightly elongated and progressively narrower distally; I with 10 complete, coarse carinae, II-IV with 8 , and $\mathrm{V}$ with none (round in cross-section): dorsal lateral carinae moderately serrate on I-II, weakly serrate on III, vestigially subserrate on IV; lateral supramedian carinae moderately serrate on I, weakly subserrate on II-III, vestigially serrate on IV; lateral inframedian carinae moderately crenulate on I and absent on II-V; ventral lateral carinae moderately crenulate on I-III, weakly crenulate on IV, vestigially subcrenulate on IV and absent on V (suggested by a few extremely vestigial minute granules basally); ventral submedian carinae moderately subcostate on I-II, weakly subcostate on III, vestigially subgranulose on IV; ventral median carina absent on all segments (suggested by a few extremely vestigial minute granules basally on V). Intercarinal surface matt, with some scattered minute granules that become progressively sparser and smaller distally (obsolete on V). Dorsal furrow very shallow on all segments. Two pairs of ventrolateral macrosetae, plus some inconspicuous microsetae scattered over all carinae.
Table 4

Morphometric comparison between adult females of Centruroides noxius Hoffmann, 1932 (topotypes, $n=4$ ) and its closest relative Centruroides huichol sp. n. (types, $n=4$ ), based on a selection of 6 measurements and 4 ratios. Total length has been included as a comparative complement. Abbreviations: length (L), width (W), standard deviation (SD).

\begin{tabular}{lcc}
\hline Variable & $\begin{array}{l}\text { C. } \text { noxius } \\
\text { (mean } \pm \text { SD) }\end{array}$ & $\begin{array}{l}\text { C. huichol sp. n. } \\
\text { (mean } \pm \text { SD) }\end{array}$ \\
\hline Pedipalp manus (L) & $2.43 \pm 0.33$ & $3.23 \pm 0.15$ \\
Pedipalp manus (W) & $1.64 \pm 0.24$ & $2.00 \pm 0.03$ \\
Metasomal segment II (W) & $2.24 \pm 0.20$ & $2.67 \pm 0.05$ \\
Metasomal segment III (W) & $2.25 \pm 0.24$ & $2.67 \pm 0.05$ \\
Metasomal segment IV (W) & $2.18 \pm 0.27$ & $2.63 \pm 0.08$ \\
Metasomal segment V (W) & $2.12 \pm 0.25$ & $2.63 \pm 0.03$ \\
Pedipalp manus (L/W) & $1.48 \pm 0.03$ & $1.62 \pm 0.08$ \\
Metasomal segment II (L/W) & $1.51 \pm 0.07$ & $1.41 \pm 0.04$ \\
Metasomal segment III (L/W) & $1.67 \pm 0.03$ & $1.52 \pm 0.03$ \\
Metasomal segment V (L/W) & $2.30 \pm 0.06$ & $2.08 \pm 0.13$ \\
Total (L) & $32.10-43.46$ & $33.56-44.62$ \\
\hline
\end{tabular}

Telson (Fig. 7g): sparsely setose, with some inconspicuous, scattered microsetae throughout surface. Vesicle inflated, oval (1.65 times longer than wide, 1.13 times wider than deep), surface matt, without any traces of granules, ventral median carina indistinct. Subaculear tubercle large and spiniform, close to the base of aculeus, pointing toward its base and ornate with a ventral granule. Aculeus relatively thick, conspicuously shorter than vesicle and strongly curved.

Female (paratype: Fig. 9; Tables 2, 4-5). Sexual dimorphism reduced, but evident: (1) pedipalp manus shorter and rounder; (2) carapace and tergites with glossy granulation finer; (3) genital papillae absent; (4) pectines somewhat narrower and shorter, not reaching the coxa-trochanter joint of leg IV, with slightly lower tooth count; (5) basal pectinal plate larger, with posterior margin convex and with a large and very deep, transverse central pit; (6) mesosoma markedly wider, with sides strongly convex; (7) metasomal segments and telson slightly shorter and more robust; (8) metasomal segments with slightly more developed carinae, especially the ventral submedian and ventral laterals which are complete on $\mathrm{V}$.

Variation. Adult size varied from 30.9 to $40.7 \mathrm{~mm}$ in males $(n=9)$ and 33.6 to $44.6 \mathrm{~mm}$ in females $(n=9)$. The examined sample contains 2 size-classes among adults of each sex and in each class, males are smaller than females (Table 2). As in $C$. noxius (see above), such a correlation deviates from the genus standard and smaller adults invariably exhibit the weaker expression of secondary sexual dimorphic characters such as morphometric ratios of pedipalps and metasoma.

The base color presented only minor variations among different individuals, some being subtly paler and some others somewhat darker; in all cases such variation was clearly agerelated, i.e., darker specimens were always the oldest (e.g., cheliceral dentition, leg claws and body setation markedly worn down) and vice versa. Nevertheless, as previously described for C. noxius (see above), the dark pattern shows 2 different configurations without any intermediate forms (Fig. 10): (1) the stripped pattern described for the holotype; (2) a confluent pattern, with patches on carapace and tergites larger and densely 

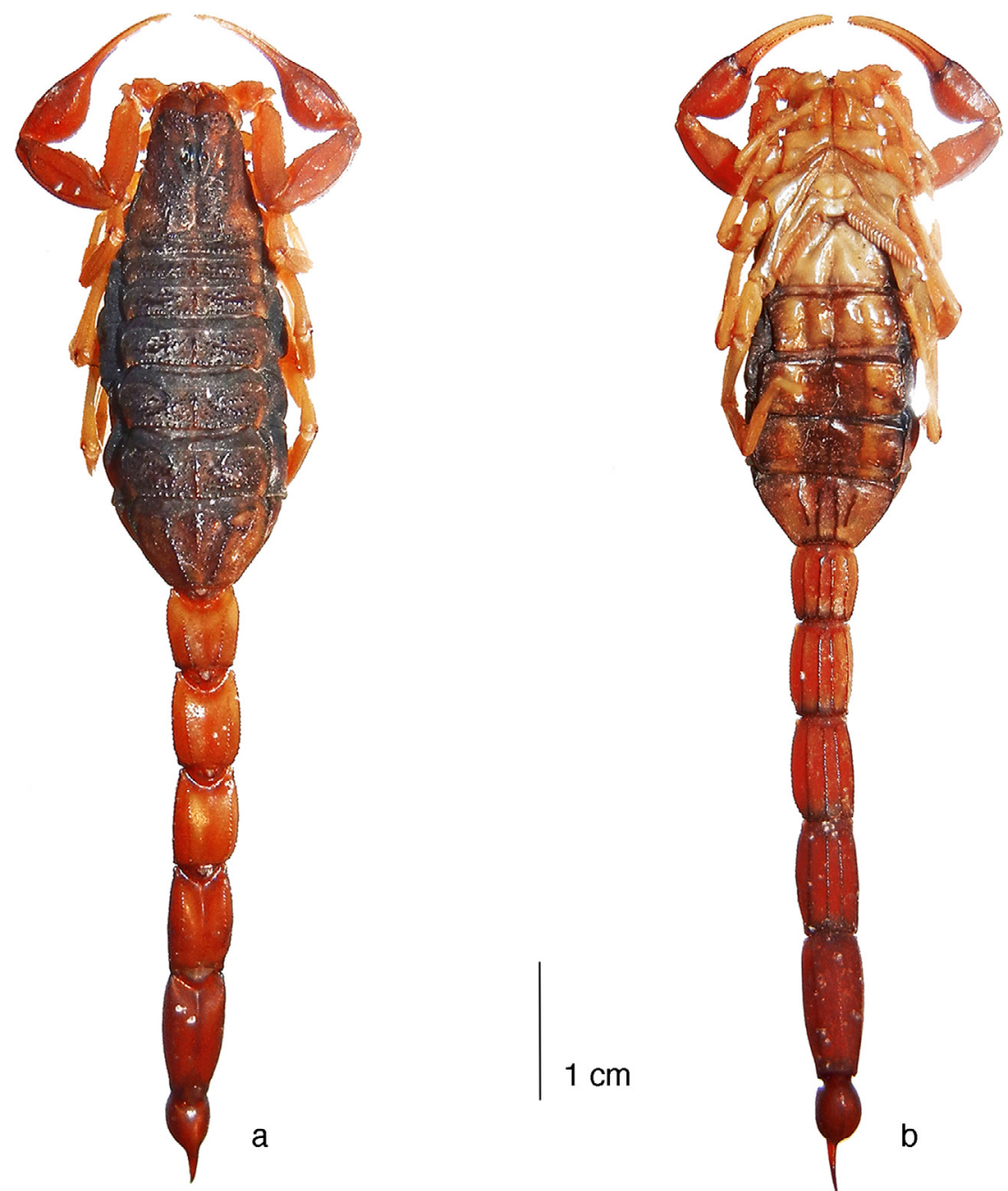

Figure 8. Average-sized adult female (paratype) of Centruroides huichol sp. n., habitus: a, dorsal; b, ventral.

interconnected without clearly defined pattern of longitudinal stripes.

Pectinal tooth counts varied as follows: 18-21 in males, 17-19 in females (Table 5). As mentioned for the preceding species, there was no clearly defined mode in either sex of C. huichol sp. $\mathrm{n}$. The number of median rows of granules in pedipalp fingers was 8 in all specimens examined. The apical subrow of movable finger was asymmetrical ( $2 / 3$ granules) between both pedipalps in most specimens.

\section{Taxonomic summary}

Type data. Mexico: Nayarit: San Blas Municipality: Guadalupe Victoria: Escuela Secundaria "Tierra y Libertad \# $3^{\prime \prime} ; 21^{\circ} 40^{\prime} 47^{\prime \prime} \mathrm{N}, 105^{\circ} 19^{\prime} 39^{\prime \prime} \mathrm{W} ; 10 \mathrm{~m}$ asl; 23/ii/2008; col. M. A. Villaseñor; 10 holotype (CNAN-T0981), 10, 2 \% paratypes (CNAN-T0982 Paratypes: 10 (CAFBUM 20150500), 3ㅇ, CAFBUM 2015-0501), 6/iv/2008; cols. J. PonceSaavedra, A. F. Quijano; 2 \% paratypes (CAFBUM 2015-0502).

Table 5

Pectinal tooth count variation in Centruroides noxius Hoffmann, 1932 (topotypes) and its closest relative Centruroides huichol sp. n. (types). Abbreviations: number of pectines $(n)$.

\begin{tabular}{|c|c|c|c|c|c|c|c|}
\hline \multirow[t]{2}{*}{ Species } & \multirow[t]{2}{*}{ Sex } & \multirow[t]{2}{*}{$n$} & \multicolumn{5}{|c|}{ Pectinal tooth count } \\
\hline & & & 17 & 18 & 19 & 20 & 21 \\
\hline \multirow{2}{*}{ C. noxius } & $0^{7} \sigma^{7}$ & 18 & & 2 & 7 & 7 & 2 \\
\hline & 우우 & 6 & 2 & 2 & 2 & & \\
\hline \multirow{2}{*}{ C. huichol sp. n. } & $0^{n} 0^{7}$ & 18 & & 5 & 4 & 7 & 2 \\
\hline & 우우 & 18 & 2 & 9 & 7 & & \\
\hline
\end{tabular}



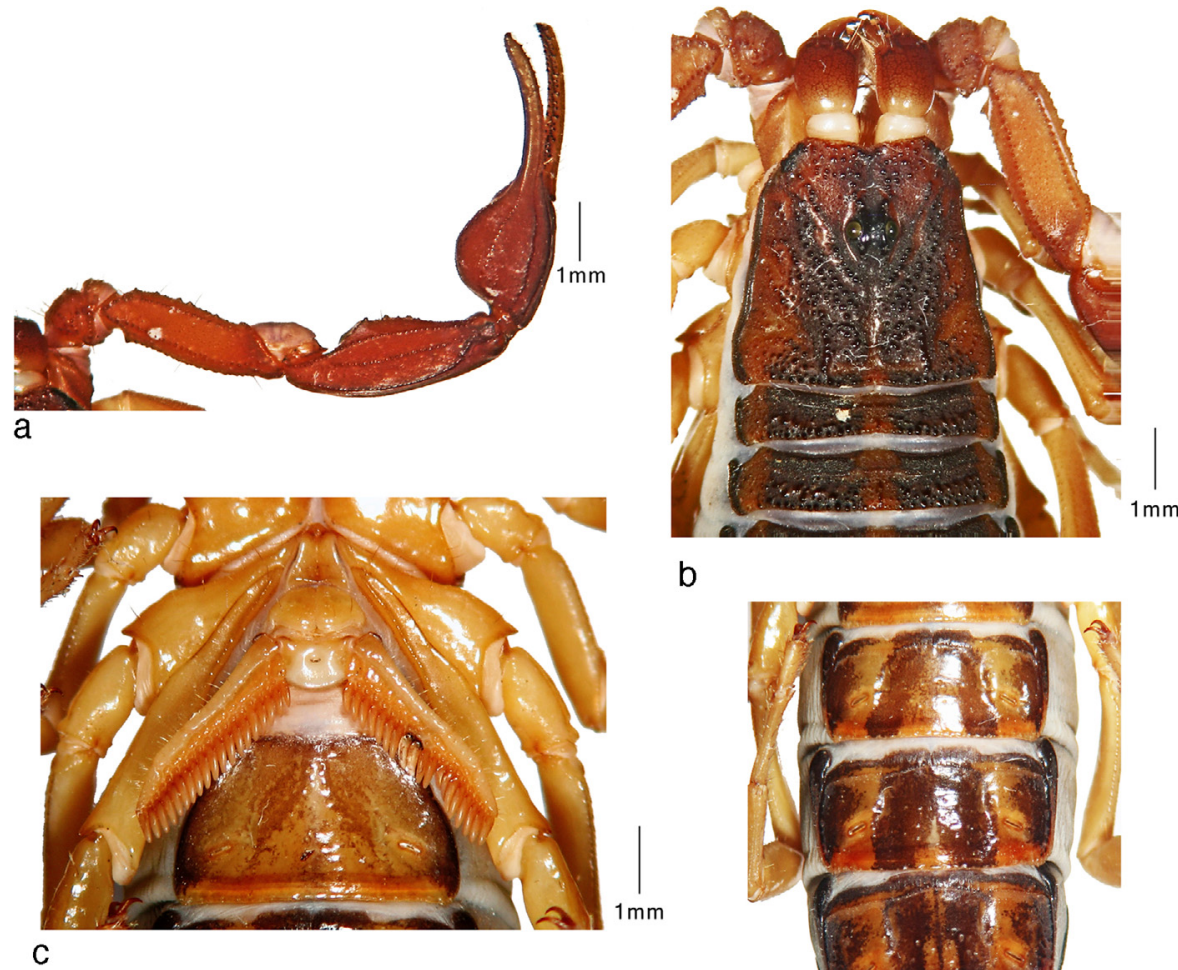

b
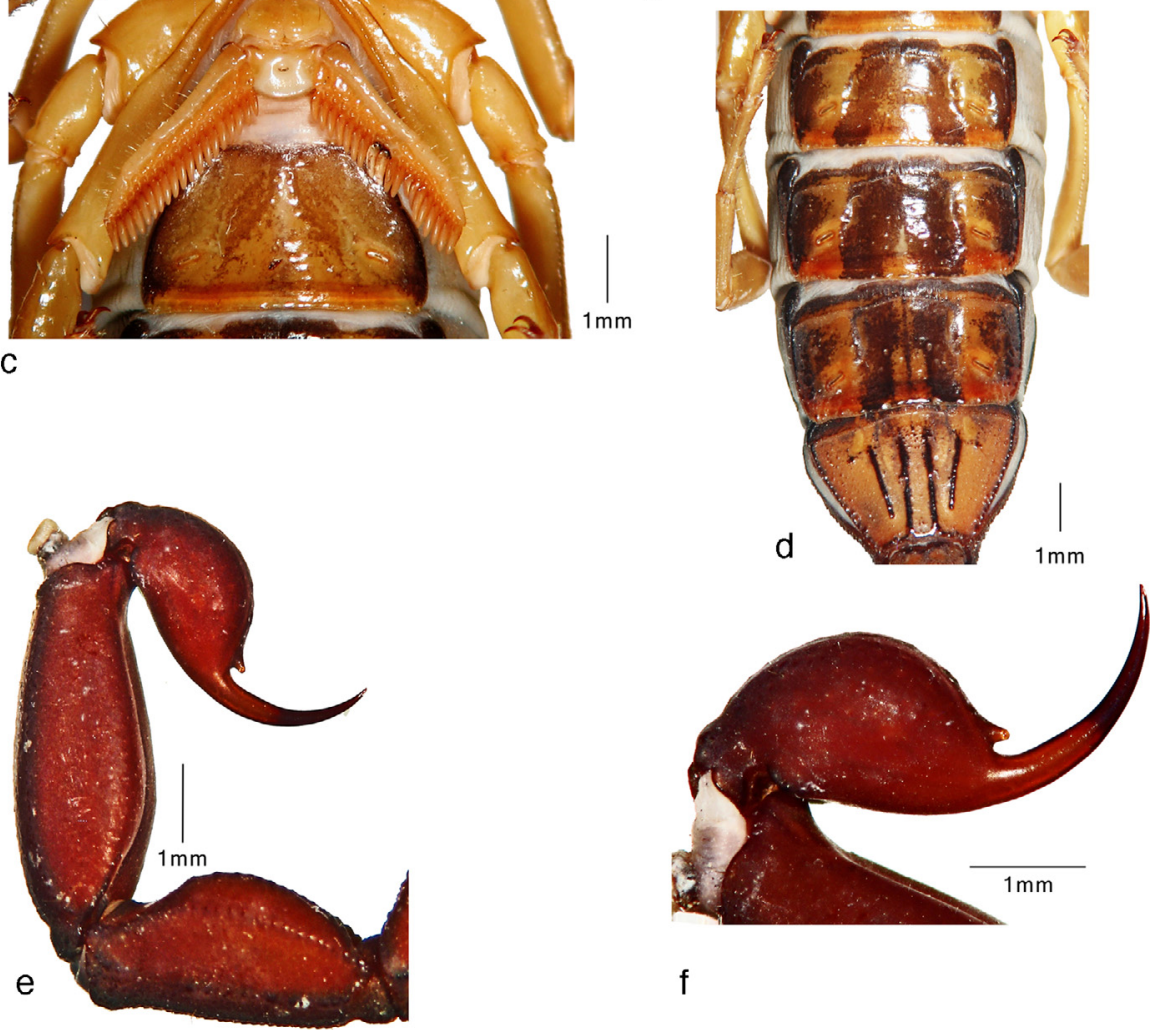

$f$

Figure 9. Average-sized adult female (paratype) of Centruroides huichol sp. n.: a, pedipalp, dorsal view; b, carapace and tergites I-II; c, sternopectinal region; $\mathrm{d}$, sternites IV-VII; e, metasomal segments IV-V and telson, lateral view; f, telson, lateral view.

Other material examined: San Blas Municipality: Guadalupe Victoria: Escuela Secundaria "Tierra y Libertad \# 3"; $21^{\circ} 40^{\prime} 47^{\prime \prime} \mathrm{N}, \quad 105^{\circ} 19^{\prime} 39^{\prime \prime} \mathrm{W} ; 10 \mathrm{~m}$ asl; 23/ii/2008; col. M. A. Villaseñor; 2 juvenile topotypes (CAFBUM); 6/iv/2008; cols. J. Ponce-Saavedra, A. F. Quijano; $3 \sigma^{7} \sigma^{7}$, 3oq, 1 juvenile topotypes (COEyB).

Etymology. The specific epithet selected honors the Huichol (= Wixarika) people, one of the native inhabitants of Nayarit; and it is used as a noun in apposition.

Distribution (Fig. 11). This scorpion is known only from the type locality, in the Pacific Coastal Plain of central Nayarit. All specimens of the type-series were collected inside a junior high school.

\section{Remarks}

Based upon size, general morphology and coloration, this species is closely related only to $C$. noxius, but can be reliably distinguished by: (1) pedipalps relatively shorter, with chelae swollen; (2) pedipalp manus with all carinae of dorsoexternal surface more stronger developed, and intercarinal granulation of internal surface considerably finer and sparser; (3) carapace and tergites (especially in males) with the intercarinal granulation sparser but larger, and with carinal granulation coarser and partially fused; (4) basal plate of pectines with the discal pit considerably larger, deeper and widely transverse-oval in shape; (5) metasoma conspicuously less slender, with all segments shorter, wider and deeper, with sides somewhat convex; 

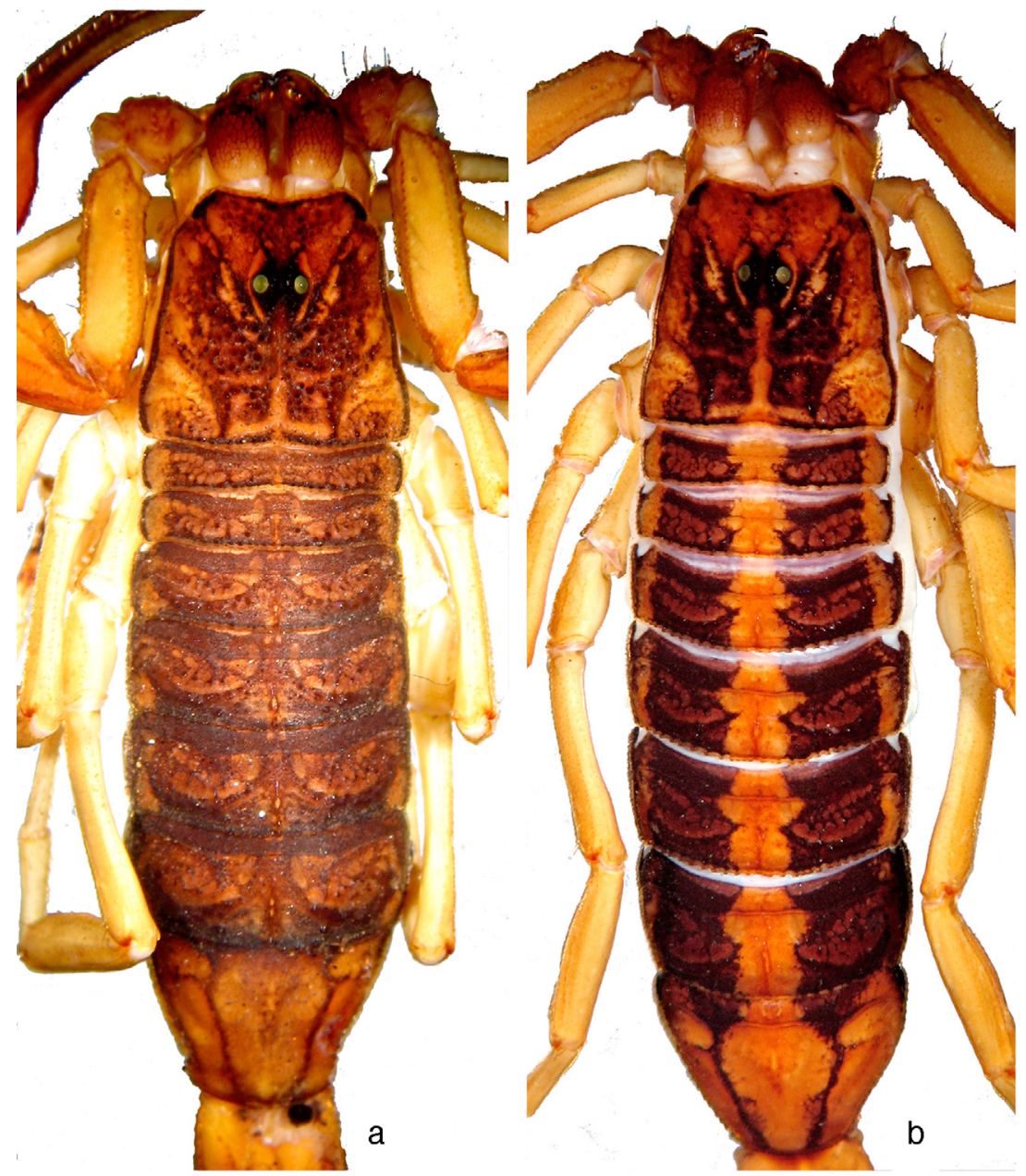

Figure 10. Adult male paratypes of Centruroides huichol sp. n., dimorphic color patterns: a, confluent; b, stripped.

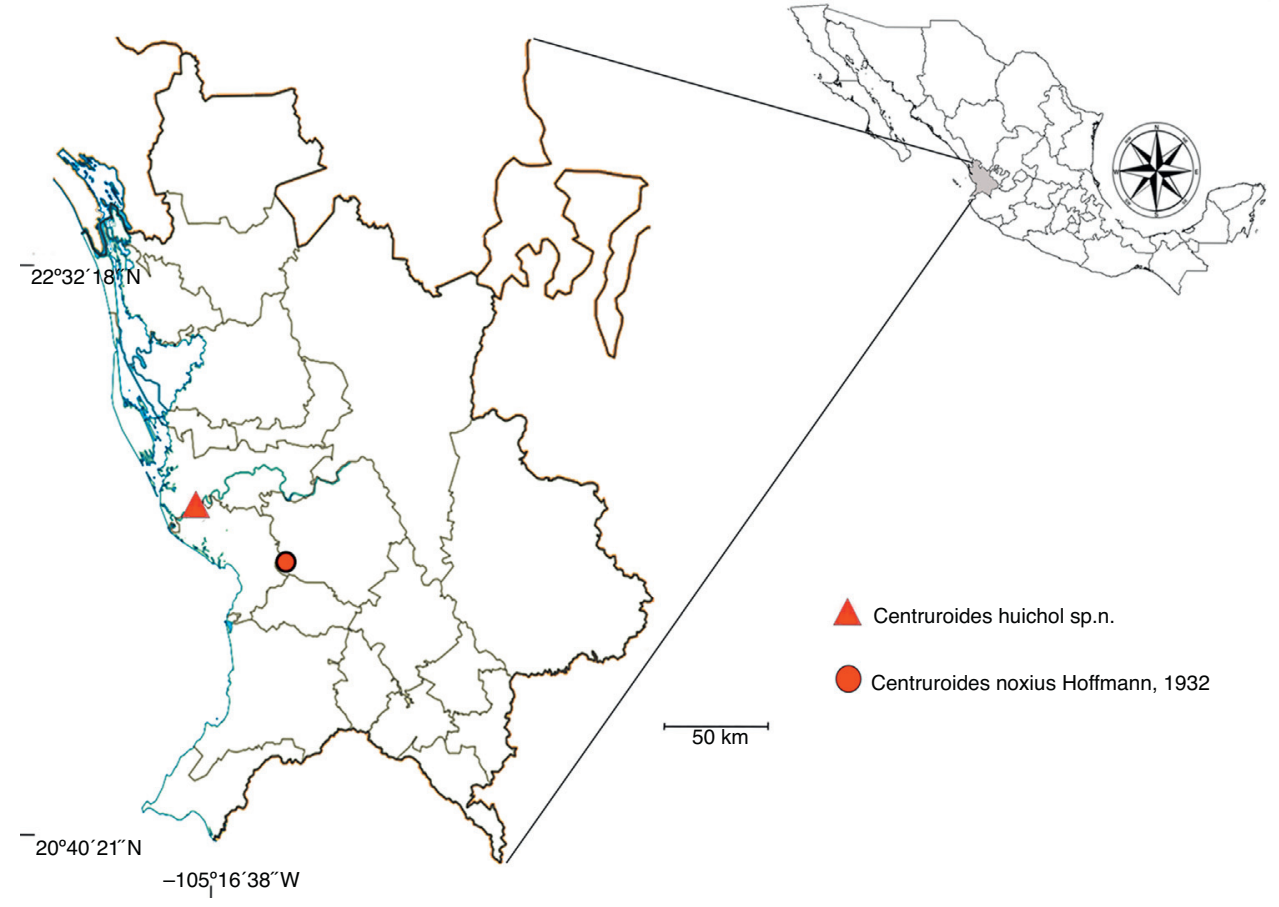

Figure 11. Type localities of Centruroides noxius Hoffmann, 1932 and Centruroides huichol sp. $\mathrm{n}$. in Nayarit, Mexico. Modified from Inegi (1997). 
(6) metasomal segments with carinae weaker but coarser in both sexes, and with intercarinal granulation almost entirely absent on females, especially on V; (7) telson vesicle markedly swollen.

These same characters compare in $C$. noxius as follows: (1) pedipalps relatively longer, with chelae oval; (2) pedipalp manus with all carinae of dorsoexternal surface not as strongly developed, and intercarinal granulation of internal surface considerably coarser and denser; (3) carapace and tergites (especially in males) with the intercarinal granulation denser but finer, and with carinal granulation finer and not fused; (4) basal plate of pectines with the discal pit considerably smaller, shallower and almost circular in shape; (5) metasoma conspicuously more slender, with all segments longer, narrower and flatter, with sides essentially straight; (6) metasomal segments with carinae more finely serrate in both sexes, and with intercarinal granulation abundant in females, especially on V; (7) telson vesicle not swollen.

Further, even though the coloration in Centruroides spp. is usually variable and of limited value to diagnose many closely related taxa, there are 4 sharp differences that appear consistent in the sample examined: (1) the overall base color is plain brown in $C$. noxius, but has a vivid, intense red shade in $C$. huichol sp. n.; (2) the dark pattern of chelicerae becomes paler and sparser distally in C. noxius, but darker and denser in C. huichol sp. n.; (3) the space between metasomal ventral submedian carinae is densely infuscate in $C$. noxius, but immaculate in $C$. huichol sp. n.; (4) the sternites are moderately to diffusely infuscate in $C$. noxius, but very densely infuscate in a broadly longitudinally striped pattern in $C$. huichol sp. n.

During a visit to CNAN collection in July 2014, the first author examined an uncataloged vial that contained a few unlabeled, albeit well-preserved specimens of $C$. huichol sp. n. Due to lack of data, this sample was not included in the type-series nor any morphometric or meristic data were taken, we note only the brief observation that both coloration patterns described above are present.

\section{Acknowledgments}

We are very grateful to Oscar F. Francke (Instituto de Biología, Universidad Nacional Autónoma de México) for his kind support over the years: the specimens either loaned or donated to the authors (including most specimens of $C$. noxius examined herein), the literature provided, and all the facilities repeatedly given to study the great CNAN collection under his care (especially to Rolando Teruel during a summer visit in 2014), as well as for the review of the present manuscript. Luis F. De Armas (Instituto de Ecología y Sistemática, Havana, Cuba) also contributed greatly by sending crucial literature and reviewing the manuscript. We also thank other friends and colleagues who provided us with pertinent and usually hard-to-find literature: František Kovařík (Prague, Czech Republic), Michael E. Soleglad (Winchester, California, USA), Victor Fet (Marshall University at Huntington, West Virginia, USA), and Gérard Dupré (Association Pour la Connaissance des Invertébrés, Villeneuve St. Georges, France).

\section{References}

Acosta, L. E., Candido, D. M., Buckup, E. H., \& Brescovit, A. D. (2008). Description of Zabius gaucho (Scorpiones, Buthidae), a new species from southern Brazil, with an update about the generic diagnosis. The Journal of Arachnology, 36, 491-501.

Anguiano, G. A. (1999). Evaluación de la fracción CN F.II.5 del alacrán mexicano Centruroides noxius (Hoffmann) en la generación de una respuesta inmune protectora a mamíferos. Thesis, Facultad de Ciencias, Universidad Nacional Autónoma México.

Bakvy, N., Zhang, R., Coffield, J., Maksymovych, A., \& Simpson, L. L. (1994). Effects of $\mathrm{n}-\mathrm{m}$ transmission of three scorpion neurotoxins are compared Charybdotoxin (CTX), Iberotoxin (IbTX) and Noxiustoxin (NTX). Toxicon, 33, 257-306.

Beutelspacher, B. C. R. (2000). Catálogo de los alacranes de México. Morelia: Universidad Michoacana de San Nicolás de Hidalgo.

De Armas, L. F., \& Martín-Frías, E. (2003). Nueva especie de Centruroides Marx, 1890 (Scorpiones: Buthidae) del estado de Veracruz, México. Revista Ibérica de Aracnología, 7, 205-209. Available online at: http://www.sea-entomologia.org/PDF/RIA_7/R07-027-205.pdf

De Armas, L. F., \& Martín-Frías, E. (2008). El género Centruroides Marx, 1890 (Scorpiones: Buthidae) en el estado de Veracruz, México. Boletín de la Sociedad Entomológica Aragonesa, 43, 7-22.

De Armas, L. F., Martín-Frías, E., \& Estévez-Ramírez, J. (2003). Lista anotada de las especies mexicanas del género Centruroides Marx, 1890 (Scorpiones: Buthidae). Revista Ibérica de Aracnología, 8, 93-98.

De Armas, L. F., Martín-Frías, E., \& Paniagua-Solís, J. F. (2004). Taxonomic comments about some Mexican scorpions of the genus Centruroides (Scorpiones: Buthidae). Anales de la Escuela Nacional de Ciencias Biológicas, 47, 167-171

De Armas, L. F., Teruel, R., \& Kovař́k, F. (2011). Redescription of Centruroides granosus (Thorell, 1876) and identity of Centrurus granosus simplex Thorell, 1876 (Scorpiones: Buthidae). Euscorpius, 127, 1-11.

Dent, M. A., Possani, L. D., Ramirez, G. A., \& Fletcher, P. L., Jr. (1980). Purification and characterization of two mammalian toxins from the venom of the Mexican scorpion Centruroides noxius Hoffmann. Toxicon, 18, 343-350.

Díaz-Nájera, A. (1964). Alacranes de la República Mexicana. Identificación de ejemplares capturados en 235 localidades. Revista del Instituto de Salubridad y Enfermedades Tropicales, 24, 15-30.

Díaz-Nájera, A. (1966). Alacranes de la República Mexicana. Clave para identificar especies de Centrurus (Scorpionida: Buthidae). Revista de Investigación de Salud Pública, 26, 109-123.

Díaz-Nájera, A. (1975). Listas y datos de distribución geográfica de los alacranes de México (Scorpionida). Revista de Investigación de Salud Pública, 35, $1-36$.

Dupré, G. (2013). Worldwide bibliography of scorpions. Antiquity to nowadays (Second Edition). Paris: Éditions Arachnides.

Fet, V., \& Lowe, G. (2000). Family Buthidae C. L. Koch, 1837. In V. Fet, W. D. Sissom, G. Lowe, \& M. E. Braunwalder (Eds.), Catalog of the scorpions of the world (pp. 54-286). New York: The New York Entomological Society.

Francke, O. F. (1977). Scorpions of the genus Diplocentrus Peters from Oaxaca, Mexico. Journal of Arachnology, 4, 145-200.

Frau, A., Pisciotta, M., Gurrola, G. B., Possani, L. D., \& Prestipino, G. (2001). Synthetic undecapeptide (NTX10-20) of noxiustoxin blocks completely the IA potassium currents of cerebellum granular cells. European Biophysics Journal with Biophysics Letters, 29, 569-573.

Hernández, R., Gazarian, T. G., Herion, P. S., \& Gazarian, K. G. (2002). Molecular localization and crossreactivity of two epitopes of noxiustoxin from scorpion Centruroides noxius, identified by a panel of monoclonal antibodies and peptide mimotopes. Immunology Letters, 80, 97-103.

Hoffmann, C. C. (1932). Monografías para la Entomología Médica de México. Monografía Núm. 2. Los Scorpiones de México. Segunda parte: Buthidae. Anales del Instituto de Biología, Universidad Nacional Autónoma de México, 3-4, 243-361.

Hoffmann, C. C. (1938). Nuevas consideraciones acerca de los alacranes de México. Anales del Instituto de Biología, Universidad Nacional Autónoma de México, 9, 318-337. 
Inegi (Instituto Nacional de Estadística, Geografía e Informática). (1997). Estados Unidos Mexicanos. División Territorial de 1810 a 1995. Instituto Nacional de Estadística, Geografía e Informática., 149 pp.

Jouirou, B., Mosbah, A., Visan, V., Grissmer, S., M'barek, S., Fajloun, Z., et al. (2004). Cobatoxin 1 from Centruroides noxius scorpion venom: chemical synthesis, 3-D structure in solution, pharmacology and docking on $\mathrm{K}^{+}$ channels. Biochemical Journal, 377, 37-49.

Lourenço, W. R., \& Sissom, W. D. (2000). Scorpiones. In J. Llorente-Busquets, \& E. González-Soriano (Eds.), Diversidad, taxonomía y biogeografía de artrópodos de México: hacia una síntesis de su conocimiento (Vol. II) (pp. 115-135). México, DF: Universidad Nacional Autónoma de México.

Martín-Frías, E., \& De Armas, L. F. (2001). Estudio taxonómico y biogeográfico de los alacranes mexicanos del género Centruroides (Scorpiones: Buthidae). Principales problemas. In T. Payán Porras, M. Guerra Álvarez, A. Flores Díaz, \& M. A. Aguayo Saviñón (Eds.), Reflexiones sobre el megaproyecto del Istmo de Tehuantepec. Recursos, problemática y futuro (pp. 311-315). México, DF: Universidad Autónoma Metropolitana.

Martín-Frías, E., De Armas, L. F., \& Paniagua-Solís, J. F. (2005). Redescription of the Mexican scorpion Centruroides hoffmanni De Armas, 1996 (Scorpiones: Buthidae). Euscorpius, 22, 1-7.

Petricevich, V. L. (2006). Balance between pro- and anti-inflammatory cytokines in mice treated with Centruroides noxius scorpion venom. Mediators of Inflammation, 6, 54273.

Ponce-Saavedra, J., \& Francke, O. F. (2004). Una nueva especie de alacrán del género Centruroides Marx (1890) (Scorpiones, Buthidae) de la Depresión del Balsas, México. Acta Zoológica Mexicana (nueva serie), 20, 221-232.

Ponce-Saavedra, J., \& Francke, O. F. (2011). Nueva especie de alacrán del género Centruroides Marx 1890 (Scorpiones, Buthidae) del estado de Jalisco, México. Revista Mexicana de Biodiversidad, 82, 465-474.

Ponce-Saavedra, J., \& Francke, O. F. (2013). Actualización taxonómica sobre alacranes del Centro Occidente de México. Dugesiana, 20, 73-79.
Ponce-Saavedra, J., \& Moreno-Barajas, R. (2005). El género Centruroides Marx 1890 (Scorpiones: Buthidae) en México. Biológicas, 7, 42-51.

Rendón-Anaya, M., Delaye, L., Possani, L. D., \& Herrera-Estrella, A. (2012). Global transcriptome analysis of the scorpion Centruroides noxius: new toxin families and evolutionary insights from an ancestral scorpion species. PLOS One, 7, e43331.

Santibáñez-López, C. E., \& Contreras-Félix, G. A. (2013). Two new species of Centruroides Marx 1890 (Scorpiones: Buthidae) from Oaxaca, Mexico. Zootaxa, 3734, 130-140.

Selisko, B., Cosío, G., García, C., Becerril, B., Possani, L. D., \& Horjales, E. (2004). Bacterial expression, purification and functional characterization of a recombinant chimeric $\mathrm{Fab}$ derived from murine $\mathrm{mAb} \mathrm{BCF} 2$ that neutralizes the venom of the scorpion Centruroides noxius Hoffmann. Toxicon, 43, 43-51.

Soleglad, M. E., \& Fet, V. (2003). The scorpion sternum: structure and phylogeny (Scorpiones: Orthosterni). Euscorpius, 5, 1-34.

Stahnke, H. L. (1970). Scorpion nomenclature and mensuration. Entomological News, 81, 297-316.

Stahnke, H. L., \& Calos, M. (1977). A key to the species of the genus Centruroides Marx (Scorpionida: Buthidae). Entomological News, 88, 111-120.

Teruel, R. (2000). Taxonomía del complejo Centruroides anchorellus De Armas, 1976 (Scorpiones: Buthidae). Revista Ibérica de Aracnología, 1, 3-12.

Teruel, R. (2011). Una nueva especie de Centruroides Marx 1890 (Scorpiones: Buthidae) de Honduras, América Central. Boletín de la Sociedad Entomológica Aragonesa, 48, 61-66.

Teruel, R., Kovařík, F., Baldazo-Monsivais, J. G., \& Hoferek, D. (2015). A new species of Centruroides of the "nigrovariatus" group (Scorpiones: Buthidae) from southern Mexico. Revista Ibérica de Aracnología, 26, 3-14.

Vachon, M. (1974). Études des caractères utilisés pour classer les familles et les genres des scorpions (Arachnides). 1. La trichobothriotaxie en arachnologie. Sigles trichobothriaux et types de trichobothriotaxie chez les Scorpions. Bulletin du Muséum National d'Histoire Naturelle, 3e série, 140 Zoologie, 104, 857-958. 